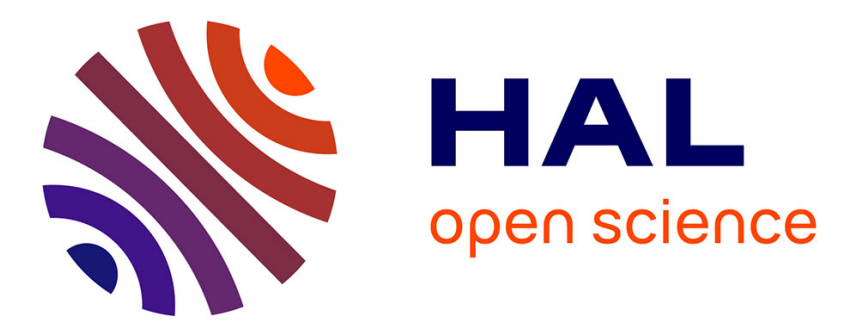

\title{
Triterpenoid saponins from Scabiosa stellata collected in North-eastern Algeria
}

Meryem Lehbili, Abdulmagid Alabdul Magid, Ahmed Kabouche, Laurence

Voutquenne-Nazabadioko, Hamid Morjani, Dominique Harakat, Zahia

Kabouche

\section{To cite this version:}

Meryem Lehbili, Abdulmagid Alabdul Magid, Ahmed Kabouche, Laurence Voutquenne-Nazabadioko, Hamid Morjani, et al.. Triterpenoid saponins from Scabiosa stellata collected in North-eastern Algeria.

Phytochemistry, 2018, 150, pp.40-49. 10.1016/j.phytochem.2018.03.005 . hal-03351420

\section{HAL Id: hal-03351420 \\ https://hal.univ-reims.fr/hal-03351420}

Submitted on 22 Sep 2021

HAL is a multi-disciplinary open access archive for the deposit and dissemination of scientific research documents, whether they are published or not. The documents may come from teaching and research institutions in France or abroad, or from public or private research centers.
L'archive ouverte pluridisciplinaire HAL, est destinée au dépôt et à la diffusion de documents scientifiques de niveau recherche, publiés ou non, émanant des établissements d'enseignement et de recherche français ou étrangers, des laboratoires publics ou privés. 


\title{
Triterpenoid saponins from Scabiosa stellata collected in North-eastern
}

\author{
Algeria \\ Meryem Lehbili ${ }^{\mathrm{a}, \mathrm{b}}$, Abdulmagid Alabdul Magid ${ }^{\mathrm{b}, *}$, Ahmed Kabouche ${ }^{\mathrm{a}}$, Laurence Voutquenne- \\ Nazabadioko $^{\mathrm{b}}$, Hamid Morjani ${ }^{\mathrm{c}}$, Dominique Harakat ${ }^{\mathrm{d}}$, Zahia Kabouche ${ }^{\mathrm{a}}$ \\ aUniversité des frères Mentouri-Constantine, Département de chimie, Laboratoire d'Obtention \\ des Substances Thérapeutiques (LOST), Campus Chaabet-Ersas, 25000 Constantine, Algeria

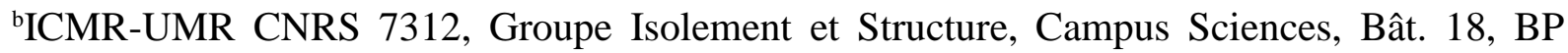 \\ 1039, 51687 Reims, France

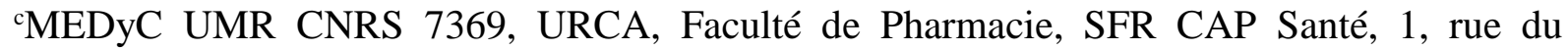 \\ Maréchal-Juin, 51096 Reims, France \\ ${ }^{\mathrm{d}}$ Service Commun d'Analyses, Institut de Chimie Moléculaire de Reims (ICMR), CNRS \\ UMR 7312, Bat. 18 B.P. 1039, 51687 Reims Cedex 2, France
}

\section{*Corresponding Author}

E-mail: abdulmagid.alabdulmagid@univ-reims.fr (A. Alabdul Magid) 


\begin{abstract}
Eight previously undescribed triterpenoid saponins, scabiostellatosides A-H (1-8), and three known compounds were isolated from the whole plant Scabiosa stellata Cav. The structures of these compounds were identified on the basis of extensive NMR and HRESIMS data analysis. Scabiostellatoside F (3- $O$-[ $\beta$-D-glucopyranosyl-( $1 \rightarrow 4)-\beta$-D-glucopyranosyl-( $1 \rightarrow 4)$ $\beta$-D-glucopyranosyl-(1 $\rightarrow 4)-\alpha$-L-rhamnopyranosyl-( $1 \rightarrow 3)-\beta$-D-xylopyranosyl-( $1 \rightarrow 3)-\alpha$-Lrhamnopyranosyl-( $(\rightarrow 2)$ - $\beta$-D-xylopyranosyl]-oleanolic acid) exhibited good cytotoxic activity against fibrosarcoma cell line (HT1080) with $\mathrm{IC}_{50}$ value of $12.0 \pm 0.2 \mu \mathrm{M}$.
\end{abstract}


Keywords: Scabiosa stellate Cav., Caprifoliaceae, triterpenoid saponins, cytotoxic activity.

\section{Introduction}

Scabiosa stellata Cav., known by the common name starflower pincushions, belong to the Caprifoliaceae family. It is an endemic North African herbaceous, bristly-hairy annual plant (Pottier-Alapetite, 1981). In folk medicine, leaves and flowers of Scabiosa stellata was used in Morocco against heel cracks (Bammi and Douira, 2002). The majority of Scabiosa, comprising about 100 species, occurs in the Mediterranean region (Carlson et al., 2012) and among them, approximately 12 species can be found in Algeria (Quezel and Santa, 1963). Up to date, chemical investigations of Scabiosa species have mainly revealed the presence of saponins (Alimbaeva et al., 1977, Baykal et al., 1998, Zheng et al., 2004), flavonoids, coumarins (Garaev et al., 2008), and iridoid glucosides (Papalexandrou et al., 2003, Polat et al., 2010). The aglycone of Scabiosa saponins were identified as oleanolic acid, hederagenin, and ursolic acid with glucose, rhamnose, xylose, and arabinose as sugar (Akimaliev et al., 1976, Yusifova and Movsumov 2015, Zheng et al., 2004), or pomolic acid with glycoside containing an allose in Scabiosa rotata saponins (Baykal et al., 1997, Baykal et al., 1998). A recent study about the $n$-hexane extract of $S$. stellata showed the presence of fatty acids and derivatives, $\beta$-sitosterol, stigmasterol, oleanolic and ursolic acids (Rahmouni et al., 2017). In a continuing of our search for bioactive constituents from Algerian flora, the whole plant $S$. stellata was investigated and seven previously undescribed oleanane-type and one ursane-type triterpenoid saponins, named scabiostellatosides A-H (1-8) were isolated (Figure 1), together with three known compounds (9-11) from the hydro alcoholic extract. The cytotoxic activity of triterpenoid saponins was evaluated in vitro against fibrosarcoma (HT1080) cell line. Herein, the isolation, structural elucidation and cytotoxic activity of these compounds were described. 


\section{Results and discussion}

The dried whole plant Scabiosa stellata Cav. was extracted with $70 \% \mathrm{EtOH}$, and the concentrated extract was subjected to Diaion HP-20 resin chromatography to obtain fractions I-V. The saponins-rich fraction (IV) was separated by flash chromatography and semipreparative $\mathrm{RP}_{18}$-HPLC. A total of eleven compounds were obtained, comprising eight previously undescribed triterpenoid saponins (1-8, scabiostellatosides A-H) and 3 known compounds (Figure 1). Structural elucidation was performed by spectral methods including 1D-, 2D-NMR and HRESIMS techniques. Acid hydrolysis of an aliquot of the saponin-rich fraction (IV) allowed the identification of five monosaccharides as D-glucose, D-xylose, Dglucuronic acid, L-arabinose and L-rhamnose by comparison with authentic samples (see experimental section). The known compounds were elucidated as 3-O-[ $\beta$-D-glucopyranosyl$(1 \rightarrow 2)$ - $\beta$-D-glucuronopyranosyl]-28- $O$-[ $\beta$-D-glucopyranosyl]-hederagenin (palustroside III) (Udayama et al., 1998) (9), ursolic acid (10) (Mahato and Kundu, 1994) and 3-O-[3-O-acetyl6-O-(p-coumaroyl)- $\beta$-D-glucopyranosyl]-kaempferol (11) (Christopoulou et al., 2008). Their spectroscopic data were in perfect agreement with those reported in the literature.

Scabiostellatoside A (1) was obtained as amorphous, white powder and possessed a molecular formula of $\mathrm{C}_{64} \mathrm{H}_{104} \mathrm{O}_{29}$, deduced from the positive HRESIMS analysis $(\mathrm{m} / z$ 1359.6552, $\left.[\mathrm{M}+\mathrm{Na}]^{+}\right)$. The ${ }^{1} \mathrm{H}$ NMR spectrum showed characteristic signals of an olean-12-ene skeleton with seven methyl singlet signals at $\delta_{\mathrm{H}} 0.83,0.88,0.93,0.97,0.99,1.05$ and 1.18 , an oxymethine $\delta_{\mathrm{H}} 3.15(1 \mathrm{H}, \mathrm{dd}, J=11.6,4.2 \mathrm{~Hz})$, together with one olefinic proton resonance at $\delta_{\mathrm{H}} 5.27(1 \mathrm{H}, \mathrm{t}, J=3.4 \mathrm{~Hz})$. The ${ }^{13} \mathrm{C}$ NMR spectrum showed resonance for one carboxyl or ester group $\left(\delta_{\mathrm{C}} 176.7\right)$, two olefinic carbons $\left(\delta_{\mathrm{C}} 122.4,143.5\right)$, one oxygenated methane $\left(\delta_{\mathrm{C}}\right.$ 89.2), and seven methyls $\left(\delta_{\mathrm{C}} 14.8,15.8,16.6,22.6,24.9,27.2,32.1\right)$. Taken together, these data were indicative of a typical oleanolic acid (Alabdul Magid et al., 2015). This assumption was confirmed by analysis of the COSY, TOCSY, ROESY, HSQC and HMBC spectra which 
allowed the full assignment of the proton and carbon resonances of the aglycone (Table 1). The deshielding effect observed at $\mathrm{H}-18$ signal $\left(\delta_{\mathrm{H}} 2.86, \mathrm{dd}, J=13.9,3.8 \mathrm{~Hz}\right)$, due to magnetic anisotropy effect of carbonyl at C-28, is in agreement with a cis fusion between D and E rings. In the ROESY spectrum, correlations observed between $\mathrm{H}-3 / \mathrm{H}-5$ and $\mathrm{H}-5 / \mathrm{H}-9$ indicated their $\alpha$-axial orientation and thus the $\beta$-orientation of the oxygen at C-3. The ROESY correlations between $\mathrm{H}_{3}-23 / \mathrm{H}-5$ and $\mathrm{H}-9$ and $\mathrm{H}-9 / \mathrm{H}_{3}-27$ indicated the $\alpha$-orientation of $\mathrm{CH}_{3}-23$ and $\mathrm{CH}_{3}-27$. In the same manner, the ROESY correlations between $\mathrm{H}_{3}-25 / \mathrm{H}_{3}-24$, $\mathrm{H}_{3}-25 / \mathrm{H}_{3}-26, \mathrm{H}_{3}-26 / \mathrm{H}-18, \mathrm{H}-18 / \mathrm{CH}_{3}-30$ indicated their $\beta$-axial orientation. The chemical shifts of C-3 $\left(\delta_{\mathrm{C}} 89.2\right)$ and C-28 $\left(\delta_{\mathrm{C}} 176.7\right)$ revealed that 1 is a bisdesmosidic glycoside. The sugar part of 1 consists of six residues as evidenced by ${ }^{1} \mathrm{H}$ and ${ }^{13} \mathrm{C}$ NMR spectra which displayed six anomeric protons at $\delta_{\mathrm{H}} 4.36(\mathrm{~d}, J=7.8 \mathrm{~Hz}), 4.49(\mathrm{~d}, J=7.6 \mathrm{~Hz}), 4.51(\mathrm{~d}, J=5.3$ $\mathrm{Hz}), 5.19(\mathrm{~d}, J=1.5 \mathrm{~Hz}), 5.20(\mathrm{~d}, J=1.7 \mathrm{~Hz})$ and $5.37(\mathrm{~d}, J=8.1 \mathrm{~Hz})$, which correlated in the HSQC spectrum to carbons at $\delta_{\mathrm{C}} 103.3,105.1,103.9,101.1,100.1$ and 94.4 , respectively (Table 2). All the protons within each monosaccharide spin system were delineated, starting from the anomeric protons, using COSY, TOCSY and ROESY spectra. After assignments of the protons, the ${ }^{13} \mathrm{C}-\mathrm{NMR}$ resonances of each sugar unit were identified by HSQC and further confirmed by HMBC. All the monosaccharides were determined to be in pyranose form by their ${ }^{13} \mathrm{C}-\mathrm{NMR}$ data and confirmed by ROESY spectrum. In this way, two $\alpha$-Lrhamnopyranose units (rha and rha') were easily identified both by equatorial anomeric protons $\left(\delta_{\mathrm{H}} 5.20, \mathrm{~d}, J=1.5 \mathrm{~Hz}\right.$, rha; $5.19, \mathrm{~d}, J=1.4 \mathrm{~Hz}$, rha' $)$ and $6.2 \mathrm{~Hz}$ methyl doublets $\left(\delta_{\mathrm{H}}\right.$ 1.24, rha; $\left.1.27, \mathrm{rha}^{\prime}\right)$. The presence of these rha and rha' was confirmed from their typical pattern in the ${ }^{1} \mathrm{H}-\mathrm{NMR}$ spectrum; the small coupling constant between $\mathrm{H}-2$ and $\mathrm{H}-3\left(J_{\mathrm{H}-2 \mathrm{eq}, \mathrm{H}-}\right.$ $3 \mathrm{ax}=3.5 \mathrm{~Hz})$ and the large coupling constants between $\mathrm{H}-3$ and $\mathrm{H}-4 J_{\mathrm{H}-3 \mathrm{ax}, \mathrm{H}-4 \mathrm{ax}}(\geq 9.5 \mathrm{~Hz})$ as summarized in Table 2. The $\alpha$-configuration of rha and rha' also was confirmed by the chemical shift of their C-5 ( $\left.\delta_{\mathrm{C}} 68.6\right)$ (Chang et al., 2007). The rha unit $\left(\delta_{\mathrm{H}-1} 5.20\right)$ was 
revealed to be C-3 mono-substituted $\left(\delta_{\mathrm{C}-3} 80.6\right)$ whereas the rha' unit ( $\left.\delta_{\mathrm{H}-1} 5.19\right)$ was found to be in terminal position (Table 2). Starting from the anomeric proton signals at $\delta_{\mathrm{H}} 5.37$ and 4.36, the NMR signals belonging to each system were assigned to two $\beta$-D-glucopyranose units $\left(\mathrm{glc}, \delta_{\mathrm{H}-1} 5.37 ; \mathrm{glc}^{\prime}, \delta_{\mathrm{H}-1} 4.36\right)$ because H-2, H-3 and H-4 exhibit large, anti-vicinal couplings $\left(\geq 7.8 \mathrm{~Hz}\right.$ ) indicating that all are axials (Table 2). The relatively large ${ }^{3} J_{\mathrm{H}-1, \mathrm{H}-2}$ values of the glc and $\operatorname{glc}^{\prime}(7.8-8.1)$, indicated a $\beta$ anomeric orientation for the both glucopyranose units. The considerably downfield shift of C-6 of the glc unit ( $\left.\delta_{\mathrm{C}-6} 68.1\right)$ suggested that glc was 6-monosubstituted. This was confirmed by the existence of an HMBC cross-peak between glc'-H-1 and glc-C-6. The fifth sugar unit was identified as $\alpha$-Larabinopyranose (ara, $\delta_{\mathrm{H} 1} 4.51, \mathrm{~d}, J=5.3 \mathrm{~Hz}$ ). The relatively large ${ }^{3} J_{\mathrm{H}-1-\mathrm{H}-2}$ and ${ }^{3} J_{\mathrm{H}-2-\mathrm{H}-3}(7.1$ $\mathrm{Hz}$ ) of $\mathrm{H}-2$ require that it must be axial and has two axial neighbors. The small couplings ${ }^{3} J_{\mathrm{H}-}$ 3-H-4 $(3.4 \mathrm{~Hz})$ indicated that the $\mathrm{H}-4$ is equatorial (Table 2). The $\alpha$-arabinopyranose unit was determined to be in an $\alpha$-configuration based on the ROESY correlations observed between the $\alpha$-axial protons $\mathrm{H}-1 / \mathrm{H}-3, \mathrm{H}-3 / \mathrm{H}-5 \mathrm{ax}$ and $\mathrm{H}-1 / \mathrm{H}-5 \mathrm{ax}$. The downfield shift of $\mathrm{C}-2$ of the ara unit $\left(\delta_{\mathrm{C}-2} 75.0\right)$ suggested that it was 2 -monosubstituted. The NMR signals belonging to the ara unit assigned by interpretation of 2D-NMR spectra and confirmed by comparing the ${ }^{13} \mathrm{C}$ NMR chemical shifts with those of related systems reported in the literature (Alabdul Magid et al., 2015, Zheng et al., 2004). The last monosaccharide unit was identified as $\beta$-Dxylopyranose (xyl, $\delta_{\mathrm{H} 1} 4.49, \mathrm{~d}, J=7.6 \mathrm{~Hz}$ ) by interpretation of 2D-NMR spectra. The H-1, H2, H-3 and H-4 of xyl exhibited large vicinal couplings $(\geq 7.6 \mathrm{~Hz})$ indicating that all are axial (Table 2). The $\beta$-configuration of xyl unit was confirmed by the observation of ROESY correlations between the $\alpha$-axial protons $\mathrm{H}-1 / \mathrm{H}-3, \mathrm{H}-3 / \mathrm{H}-5 \mathrm{ax}$ and $\mathrm{H}-1 / \mathrm{H}-5 \mathrm{ax}$. The downfield shift of C-3 of the xyl unit ( $\left.\delta_{\mathrm{C}-3} 32.1\right)$ suggested that it was 3 -monosubstituted. The ${ }^{1} \mathrm{H}-$ and ${ }^{13} \mathrm{C}-\mathrm{NMR}$ spectra of $\mathbf{1}$ displayed many similarities with those of scabiosaponin A (3- $O$-[ $\beta$-D- 
glucopyranosyl-(1 $\rightarrow 4)$ - $\beta$-D-xylopyranosyl-( $1 \rightarrow 3)$ - $\alpha$-L-rhamnopyranosyl-(1 $\rightarrow 2)$ - $\alpha$-Larabinopyranonosyl]-28- $O$-[ $\beta$-D-glucopyranosyl-( $1 \rightarrow 6)$ - $\beta$-D-glucopyranosyl]-oleanolic acid) (Zheng et al., 2004), the difference was the nature and the position of attachement of last sugar residue attached to the xylose, $\alpha$-L-rhamnopyranose in $\mathbf{1}$ and $\beta$-D-glucopyranose in scabiosaponin A. The final step in the structural elucidation of $\mathbf{1}$ consisted of determination of the linkage sites both between the monosaccharide units and to the aglycone moiety. The cross-peak observed in the HMBC spectrum between glc'-H-1/glc-C-6 and glc-H-1/aglyconeC-28 established the point of attachment of the di-saccharide [ $\mathrm{glc}^{\prime}-(1 \rightarrow 6)$-glc] to the C-28 of the aglycone. In a similar fashion, the HMBC correlation between rha'-H-1/ xyl-C-3, xyl-H1/rha-C-3, rha-H-1/ara-C-2 and ara-H-1/aglycone-C-3 indicated that the tetra-saccharide

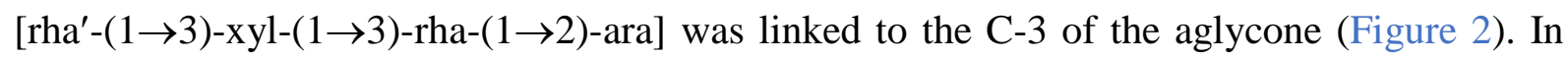
addition, ROESY correlations confirming the interglycosidic linkage and the point of attachment of the tetra-saccharide at the $\mathrm{H}-3$ of the aglycone were observed between $\mathrm{glc}^{\prime}-\mathrm{H}-$ 1/glc- $\mathrm{H}_{2}-6$, rha'-H-1/xyl-H-3, xyl-H-1/rha-H-3, rha-H-1/ara-H-2 and ara-H-1/aglycone-H-3. Based on all the foregoing evidence, scabiostellatoside A (1) was elucidated as 3-O-[ $\alpha$-L-

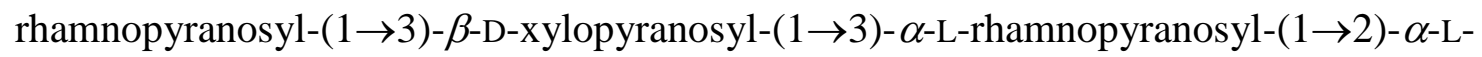
arabinopyranonosyl]-28- $O$-[ $\beta$-D-glucopyranosyl-( $1 \rightarrow 6)$ - $\beta$-D-glucopyranosyl]-oleanolic acid. The HRESIMS in the positive ion mode indicated that scabiostellatoside B (2) and (1) possessed the same molecular formula $\mathrm{C}_{64} \mathrm{H}_{104} \mathrm{O}_{29}$, as deduced from the $[\mathrm{M}+\mathrm{Na}]^{+}$ion at $m / z$ 1359.6548 (calcd for $\mathrm{C}_{64} \mathrm{H}_{104} \mathrm{O}_{29} \mathrm{Na}, 1359.6561$ ). The detailed analysis of 1D- and 2D-NMR spectra of $\mathbf{2}$ and comparison of its spectral data with those of $\mathbf{1}$ indicated the presence of the oleanolic acid as aglycone in 2, a 6-monosubstituted $\beta$-D-glucopyranose (glc, $\delta_{\mathrm{H}-1} 5.37, \mathrm{~d}, J=$ $\left.8.0 \mathrm{~Hz} ; \delta_{\mathrm{C}-6} 68.1\right)$, a terminal $\beta$-D-glucopyranose $\left(\mathrm{glc}^{\prime}, \delta_{\mathrm{H}-1} 4.36, \mathrm{~d}, J=7.8 \mathrm{~Hz}\right)$, a terminal $\alpha$ rhamnopyranose (rha', $\delta_{\mathrm{H} 1} 5.20, \mathrm{~d}, J=1.7 \mathrm{~Hz}$ ), a 3-monosubstituted $\alpha$-rhamnopyranose (rha, 
$\delta_{\mathrm{H} 1} 5.39, \mathrm{~d}, J=1.7 \mathrm{~Hz} ; \delta_{\mathrm{C}-3} 80.8$ ), and a 3 -monosubstituted $\beta$-xylopyranose (xyl', $\delta_{\mathrm{H} 1} 4.48, \mathrm{~d}$, $J=7.7 \mathrm{~Hz} ; \delta_{\mathrm{C}-3} 82.1$ ) (Table 4 ). The ${ }^{1} \mathrm{H}$ and ${ }^{13} \mathrm{C}$ NMR values of 2 were almost superimposable on those of 1 (Tables 2 and 4) excepting those corresponding to the sugar identified in $\mathbf{1}$ as 2-monosubstituted $\alpha$-L-arabinopyranose. Instead, a second $\beta$-xylopyranose unit (xyl) was identified starting from the anomeric proton $\delta_{\mathrm{H}} 4.39(\mathrm{~d}, J=7.1 \mathrm{~Hz})$, characterized by the large coupling constants $J_{\mathrm{H}-1, \mathrm{H}-2}, J_{\mathrm{H}-2, \mathrm{H}-3}$ and $J_{\mathrm{H}-3, \mathrm{H}-4}(\geq 7.1 \mathrm{~Hz})$ as summarized in Table 4 (Zheng et al., 2004). The long-rang correlations observed in the HMBC spectrum between glc'-H-1/glc-C-6, glc-H-1/aglycone-C-28, rha'-H-1/xyl'-C-3, xyl'H-1/rha-C-3, rha-H-1/xyl-C-2 and xyl-H-1/aglycone-C-3 indicated that the tetrasaccharide $\left[\right.$ rha' $^{\prime}-(1 \rightarrow 3)$-xyl'-(1 $\left.\rightarrow 3\right)-$ rha- $\left.(1 \rightarrow 2)-x y l\right]$ was linked to the $\mathrm{C}-3$ of the aglycone whereas a

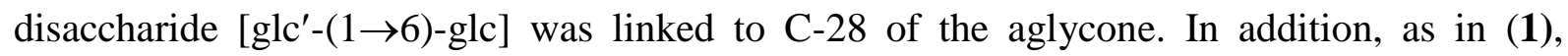
complementary pairs of ROESY correlations were found between anomeric and carbinol protons on opposite sides of the interglycosidic linkage and H-3 of the aglycone. The structure of scabiostellatoside B (2) was therefore identified as 3- $O$-[ $\alpha$-L-rhamnopyranosyl-( $1 \rightarrow 3)-\beta$-Dxylopyranosyl-( $1 \rightarrow 3)$ - $\alpha$-L-rhamnopyranosyl-( $1 \rightarrow 2)-\beta$-D-xylopyranosyl]-28- $O$-[ $\beta$-Dglucopyranosyl-( $1 \rightarrow 6)-\beta$-D-glucopyranosyl]-oleanolic acid.

The molecular formula of scabiostellatoside $\mathrm{C}$ (3) was established as $\mathrm{C}_{70} \mathrm{H}_{114} \mathrm{O}_{34}$ from the $[\mathrm{M}+\mathrm{Na}]^{+}$peak at 1521.7097 in HR-ESI-MS spectrum (calcd for $\mathrm{C}_{70} \mathrm{H}_{114} \mathrm{O}_{34} \mathrm{Na}, 1521.7089$ ). The structure of aglycone of $\mathbf{3}$ was recognized by ${ }^{1} \mathrm{H}$-and ${ }^{13} \mathrm{C}-\mathrm{NMR}$ analysis (Table 1) using the correlations observed in 2D-NMR spectra to be, as in $\mathbf{1}$ and $\mathbf{2}$, oleanolic acid. The NMR spectroscopic data of $\mathbf{3}$ were almost identical with those of $\mathbf{1}$ except for an additional hexose unit (Table 2). Extensive 2D-NMR analysis (COSY, ROESY, HSQC, HMBC, TOCSY and HSQC-TOCSY) enabled the full assignments of the resonances of six sugar units identified as 2-monosubstituted $\alpha$-L-arabinopyranonosyl (ara) $\left(\delta_{\mathrm{H}-1} 4.51, \mathrm{~d}, J=5.3 \mathrm{~Hz} ; \delta_{\mathrm{C}-2} 74.9\right), 3-$ monosubstituted $\alpha$-L-rhamnopyranosyl (rha) $\left(\delta_{\mathrm{H}-1} 5.21\right.$, brs; $\delta_{\mathrm{C}-3} 80.6$ ), 3-monosubstituted $\beta$ - 
D-xylopyranosyl (xyl) $\left(\delta_{\mathrm{H}-1} 4.49, \mathrm{~d}, J=7.6 \mathrm{~Hz} ; \delta_{\mathrm{C}-3} 81.7\right), 4$-monosubstituted $\alpha$-Lrhamnopyranosyl (rha') $\left(\delta_{\mathrm{H} 1} 5.19\right.$, brs; $\left.\delta_{\mathrm{C}-4} 82.3\right), 6$-monosubstituted $\beta$-D-glucopyranosyl (glc) $\left(\delta_{\mathrm{H}-1} 5.37, \mathrm{~d}, J=8.2 \mathrm{~Hz} ; \delta_{\mathrm{C} 6} 68.1\right)$ and terminal $\beta$-D-glucopyranosyl $\left(\mathrm{glc}^{\prime}\right)\left(\delta_{\mathrm{H}-1} 4.36, \mathrm{~d}, J=\right.$ 7.8 Hz). The supplementary hexose unit was identified as a second terminal $\beta$-Dglucopyranose unit $\left(\mathrm{glc}^{\prime \prime}\right)\left(\delta_{\mathrm{H} 1} 4.61, \mathrm{~d}, J=7.6 \mathrm{~Hz} ; \delta_{\mathrm{C}-1} 104.3\right)$. The deshielded signals of rha'C-4 $\left(\delta_{\mathrm{C}-4} 82.3\right)$ indicated that the additional glucopyranose moiety was attached to C-4 of the rha' unit. As in 1, the cross-peaks observed in the HMBC spectrum between glc'-H-1/glc-C-6 and glc-H-1/aglycone-C-28 established the point of attachment of the di-saccharide [glc'$(1 \rightarrow 6)$-glc] to the C-28 of the aglycone whereas, the HMBC correlation between $\mathrm{glc}^{\prime \prime}-\mathrm{H}-$ 1/rha'-C-4, rha'-H-1/xyl-C-3, xyl-H-1/rha-C-3, rha-H-1/ara-C-2 and ara-H-1/aglycone-C-3

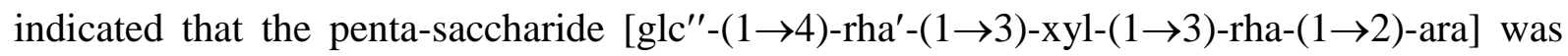
linked to the $\mathrm{C}-3$ of the aglycone. Based on all the evidences, the structure of scabiostellatoside $\mathrm{C} \quad(\mathbf{3})$ was elucidated as 3- $O$-[ $\beta$-D-glucopyranosyl-( $1 \rightarrow 4)-\alpha$-L-

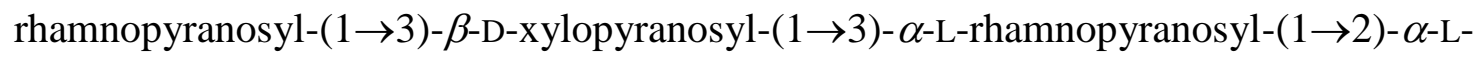
arabinopyranosyl]-28-O-[ $\beta$-D-glucopyranosyl-( $1 \rightarrow 6)$ - $\beta$-D-glucopyranosyl]-oleanolic acid. Scabiostellatoside D (4) had the same molecular formula of $\mathbf{3}\left(\mathrm{C}_{70} \mathrm{H}_{114} \mathrm{O}_{34}\right)$, deduced from the peak at $\mathrm{m} / z$ 1521.7096 $[\mathrm{M}+\mathrm{Na}]^{+}$in the HRESIMS spectrum (calcd for 1521.7089, $\left.\mathrm{C}_{70} \mathrm{H}_{114} \mathrm{O}_{34} \mathrm{Na}\right)$. The ${ }^{1} \mathrm{H}$ - and ${ }^{13} \mathrm{C}-\mathrm{NMR}$ spectra of $\mathbf{4}$ displayed many similarities with those of 3, especially for the resonances assigned to oleanolic acid, three $\beta$-D-glucopyranose units (glc, $\mathrm{glc}^{\prime}$ and $\mathrm{glc}^{\prime \prime}$ ), two $\alpha$-L-rhamnopyranose units (rha and rha') and one $\beta$-D-xylopyranose unit (xyl') (Tables 2 and 4). The identities of the monosaccharides were determined by a combination of ${ }^{1} \mathrm{H}-{ }^{1} \mathrm{H}-\mathrm{COSY}$, TOCSY, HSQC, HSQC-TOCSY, HMBC and ROESY NMR experiments. As in 2 , starting from the anomeric proton at $\delta_{\mathrm{H}-1} 4.39(\mathrm{~d}, J=7.1 \mathrm{~Hz}), 2 \mathrm{D}-\mathrm{NMR}$ spectra analysis led to the assignment of the set of protons and carbon signals of a 2- 
monosubstituted $\beta$-D-xylopyranose unit (xyl) $\left(\delta_{\mathrm{C}-2}\right.$ 76.7). Furthermore, all sites of glycosidations were also established by a HMBC experiment showing long-range correlations between glc'-H-1/glc-C-6, glc-H-1/aglycone-C-28, glc"'-H-1/rha'-C-4, rha'-H-1/xyl'-C-3, xyl'$\mathrm{H}-1 /$ rha-C-3, rha-H-1/xyl-C-2, and xyl-H-1/aglycone-C-3. Consequently, the structure of scabiostellatoside $\quad \mathrm{D} \quad(\mathbf{4})$ was established as 3- $O$-[ $\beta$-D-glucopyranosyl-(1-4)- $\alpha$-L-

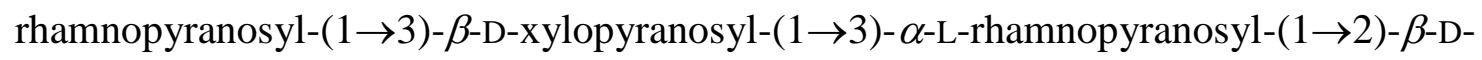
xylopyranonosyl]-28- $O$-[ $\beta$-D-glucopyranosyl-( $1 \rightarrow 6)-\beta$-D-glucopyranosyl]-oleanolic acid. The positive HRESIMS of scabiostellatoside E (5) displayed an $[\mathrm{M}+\mathrm{Na}]^{+}$ion peak at $\mathrm{m} / \mathrm{z}$ 1521.7075, corresponding to the molecular formula $\mathrm{C}_{70} \mathrm{H}_{114} \mathrm{O}_{34}$ (calcd for $\mathrm{C}_{70} \mathrm{H}_{114} \mathrm{O}_{34} \mathrm{Na}$, 1521.7089), suggesting an additional hexose unit compared to $\mathbf{1}$, as in $\mathbf{3}$. Comparison of ${ }^{1} \mathrm{H}$ and ${ }^{13} \mathrm{C}$ NMR values and the analysis of the 2D-NMR spectra showed that $\mathbf{3}$ and $\mathbf{5}$ contained the same aglycone (oleanolic acid) (Table 1). The ${ }^{1} \mathrm{H}$ and ${ }^{13} \mathrm{C}$ NMR spectra of 5 indicated the presence of seven sugar units which displayed seven anomeric protons and carbons, as in $\mathbf{3}$ (Table 2). The detailed analysis of the 2D-NMR spectra led to the identification, as in $\mathbf{3}$, of one $\alpha$-L-arabinopyranonosyl unit (ara) $\left(\delta_{\mathrm{H}-1} 4.55, \mathrm{~d}, J=6.9 \mathrm{~Hz}\right)$, two $\alpha$-L-rhamnopyranosyl units: rha $\left(\delta_{\mathrm{H}-1} 5.26, \mathrm{~d}, J=1.8 \mathrm{~Hz}\right)$ and rha' $\left(\delta_{\mathrm{H}-1} 5.19, \mathrm{~d}, J=1.6 \mathrm{~Hz}\right)$, one $\beta$-D-xylopyranosyl (xyl) $\left(\delta_{\mathrm{H}-1} 4.49, \mathrm{~d}, J=7.7 \mathrm{~Hz}\right)$ and three $\beta$-D-glucopyranosyl units: glc $\left(\delta_{\mathrm{H}-1} 5.37, \mathrm{~d}, J=8.1\right.$ $\mathrm{Hz})$, glc' $\left(\delta_{\mathrm{H}-1} 4.36, \mathrm{~d}, J=7.8 \mathrm{~Hz}\right)$ and $\operatorname{glc}^{\prime \prime}\left(\delta_{\mathrm{H}-1} 4.47, \mathrm{~d}, J=7.6 \mathrm{~Hz}\right)$ (Table 2). The deshielded signal of the C-4 carbon $\left(\delta_{\mathrm{C}-4} 78.1\right)(\Delta+10.4 \mathrm{ppm})$ of the $\alpha$-L-arabinopyranonosyl residue in $\mathbf{5}$, when compared to this in $\mathbf{3}$, suggested that the glc" unit was attached to ara-C-4. An HMBC experiment made clear all interglycosidic connectivities showing correlations between glc'-H-1/glc-C-6 ( $\left.\delta_{\mathrm{C}-6} 68.1\right)$, glc-H-1/aglycone-C-28 $\left(\delta_{\mathrm{C}-28} 176.6\right)$, glc"'-H-1/ara-C-4 $\left(\delta_{\mathrm{C}-4} 78.1\right)$, rha'-H-1/ xyl-C-3 $\left(\delta_{\mathrm{C}-3} 82.0\right)$, xyl-H-1/rha-C-3 $\left(\delta_{\mathrm{C}-3} 80.5\right)$, rha-H-1/ara-C-2 $\left(\delta_{\mathrm{C}-2}\right.$ 75.2) and ara-H-1/aglycone-C-3 $\left(\delta_{\mathrm{C}-3} 89.1\right)$. Consequently, the structure of scabiostellatoside 


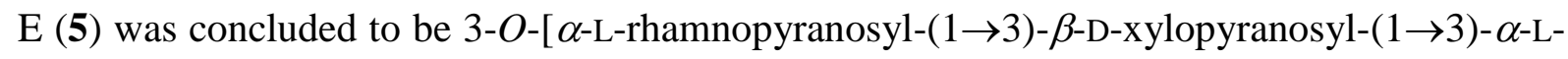
rhamnopyranosyl-(1 $\rightarrow 2)$ - $\{\beta$-D-glucopyranosyl-(1 $\rightarrow 4)-\} \alpha$-L-arabinopyranonosyl]-28- $O$-[ $\beta$-Dglucopyranosyl-(1 $\rightarrow 6)$ - $\beta$-D-glucopyranosyl]-oleanolic acid.

The HRESIMS in the positive ion mode indicated that scabiostellatoside F (6) and compound 5 possessed the same molecular formula $\mathrm{C}_{70} \mathrm{H}_{114} \mathrm{O}_{34}$, as deduced from the $[\mathrm{M}+\mathrm{Na}]^{+}$ion at $m / z, 1521.7080$ (calcd for $\mathrm{C}_{70} \mathrm{H}_{114} \mathrm{O}_{34} \mathrm{Na}, 1521.7089$ ). Comparison of ${ }^{1} \mathrm{H}$ and ${ }^{13} \mathrm{C}$ NMR values of $\mathbf{6}$ with those of $\mathbf{2}$ and $\mathbf{4}$ and the analysis of the 2D-NMR spectra showed that $\mathbf{6}$ was a 3monodesmoside of oleanolic acid $\left(\delta_{\mathrm{C}-3} 88.9\right.$ and $\left.\delta_{\mathrm{C} 28} 179.8\right)$ (Table 3$)$. The NMR data (Table 4) indicated the presence of seven sugar moieties which were identified by detailed analysis of the 2D-NMR spectra and by comparison of $\mathbf{6}$ spectral data with those of $\mathbf{2}$ and $\mathbf{4}$ as two $\beta$ D-xylopyranosyl units: xyl $\left(\delta_{\mathrm{H}-1} 4.40, \mathrm{~d}, J=7.2 \mathrm{~Hz}\right)$ and $\mathrm{xyl}^{\prime}\left(\delta_{\mathrm{H}-1} 4.47, \mathrm{~d}, J=7.7 \mathrm{~Hz}\right)$, two $\alpha$-L-rhamnopyranosyl units: rha $\left(\delta_{\mathrm{H}-1} 5.38, \mathrm{~d}, J=1.7 \mathrm{~Hz}\right)$ and rha' $\left(\delta_{\mathrm{H}-1} 5.21\right.$, brs $)$ and three $\beta$-D-glucopyranosyl units: glc $\left(\delta_{\mathrm{H} 1} 4.48, \mathrm{~d}, J=8.0 \mathrm{~Hz}\right), \mathrm{glc}^{\prime}\left(\delta_{\mathrm{H} 1} 4.42, \mathrm{~d}, J=7.9 \mathrm{~Hz}\right)$ and $\mathrm{glc}^{\prime \prime}$ $\left(\delta_{\mathrm{H}-1} 4.64, \mathrm{~d}, J=7.9 \mathrm{~Hz}\right)$. The deshielded signals of glc-C-4 $\left(\delta_{\mathrm{C}-4} 76.8\right)$ and glc' $-\mathrm{C}-4\left(\delta_{\mathrm{C}-4}\right.$ 79.1) suggested that there were 4-monosubstituted. This is confirmed by the HMBC correlations between the signals glc-H-1/glc'-C-4 $\left(\delta_{\mathrm{C}-4} 78.8\right)$, and glc-H-1/glc" $-\mathrm{C}-4\left(\delta_{\mathrm{C}-}\right.$ $479.1)$. In addition, the HMBC correlations glc ${ }^{\prime \prime}-\mathrm{H}-1 / \mathrm{rha}^{\prime}-\mathrm{C}-4\left(\delta_{\mathrm{C}-4} 82.6\right) \mathrm{rha}^{\prime}-\mathrm{H}-1 / \mathrm{xyl} \mathrm{l}^{\prime}-\mathrm{C}-3$ $\left(\delta_{\mathrm{C}-3} 81.7\right), x^{\prime}{ }^{\prime}-\mathrm{H}-1 /$ rha-C-3 $\left(\delta_{\mathrm{C}-3} 80.7\right)$, rha-H-1/xyl-C-2 $\left(\delta_{\mathrm{C}-2} 76.8\right)$ and xyl-H-1/aglycone-C$3\left(\delta_{\mathrm{C}-3} 88.9\right)$, defined the locations of the sugars in the molecule. Therefore, compound 6 (scabiostellatoside $\mathrm{F}$ ) was assigned as 3-O-[ $\beta$-D-glucopyranosyl-( $(1 \rightarrow 4)-\beta$-D-glucopyranosyl(1 $\rightarrow 4)$ - $\beta$-D-glucopyranosyl-(1 $\rightarrow 4)$ - $\alpha$-L-rhamnopyranosyl-( $1 \rightarrow 3)$ - $\beta$-D-xylopyranosyl-( $1 \rightarrow 3)$ $\alpha$-L-rhamnopyranosyl-(1 $\rightarrow 2)$ - $\beta$-D-xylopyranosyl]-oleanolic acid.

Scabiostellatoside G (7) exhibited in the HRESIMS analysis (positive ion mode) a pseudomolecular ion peak at $\mathrm{m} / z, 1157.5363[\mathrm{M}+\mathrm{Na}]^{+}$, consistent with the molecular formula of 
$\mathrm{C}_{54} \mathrm{H}_{86} \mathrm{O}_{25}$ (calcd for $\mathrm{C}_{54} \mathrm{H}_{86} \mathrm{O}_{25} \mathrm{Na}, 1157.5356$ ). The ${ }^{13} \mathrm{C}$-NMR spectrum (Table 5) showed 54 carbon signals, of which 24 were assigned to four sugar moieties and 30 to the aglycone including six tertiary methyl groups at $\delta_{\mathrm{C}} 12.0$ (C-24), 15.2 (C-25), 16.5 (C-26), 25.0 (C-27), $32.1(\mathrm{C}-29)$ and 22.6 (C-30), a hydroxymethyl carbon at $\delta_{\mathrm{C}} 63.4(\mathrm{C}-23)$, an oxygen-bearing methane carbon at $\delta_{\mathrm{C}} 82.3(\mathrm{C}-3)$ and an ester carbonyl group at $\delta_{\mathrm{C}} 175.7$ (C-28). Furthermore, olefinic carbon signals appeared at $\delta_{\mathrm{C}} 122.4(\mathrm{C}-12)$ and $143.5(\mathrm{C}-13)$ which was also confirmed by the signal at $\delta_{\mathrm{H}} 5.27(\mathrm{t}, J=3.4 \mathrm{~Hz})$ due to $\mathrm{H}-12$ in the ${ }^{1} \mathrm{H}-\mathrm{NMR}$ spectrum. All these data are characteristic of hederagenin (3 $\beta, 23$-dihydroxy-12-oleanen-28-oic acid) as in palustroside III (9) (Udayama et al., 1998). Complete assignment of each proton and carbon signals of the hederagenin was achieved by extensive 2D-NMR analysis and in good agreement with data given in the literature (Table 5) (Alabdul Magid et al., 2006; Udayama et al., 1998). The $\delta_{\mathrm{C}}$ values of C-3 and C-28 suggested that compound 7 was a bidesmosidic hederagenin glycoside with saccharide units attached to these positions, as in 9. A quick inspection of the ${ }^{1} \mathrm{H}$ and ${ }^{13} \mathrm{C}$ NMR spectra of 7 indicated the presence of four monosaccharide units through the easily identifiable signals for their anomeric protons $\left(\delta_{\mathrm{H}} 4.36,4.56,4.71\right.$ and 5.37) and carbons $\left(\delta_{\mathrm{C}} 94.4,102.8,103.2\right.$ and 103.2). The analysis of COSY, TOCSY, ROESY, HSQC and HMBC experiments led to the identification of a $\beta$-D-glucuronic acid unit starting from the anomeric proton at $\delta_{\mathrm{H}} 4.56(\mathrm{~d}, J=7.5 \mathrm{~Hz})$, characterized by a five spin system possessing large coupling constants $\left(J_{\mathrm{H}-1, \mathrm{H}-2}, J_{\mathrm{H}-2, \mathrm{H}-3}, J_{\mathrm{H}-3, \mathrm{H}-4}\right.$, and $\left.J_{\mathrm{H}-4, \mathrm{H}-5} \geq 7.5 \mathrm{~Hz}\right)$, a doublet axial proton $\mathrm{H}-5\left(J_{\mathrm{H}-4, \mathrm{H}-5}=9.0 \mathrm{~Hz}\right)($ Table 6$)$ and a carbonyl C-6 at $\delta_{\mathrm{C}} 176.2$ coupled with $\mathrm{H}-5$ of the same sugar in the HMBC spectrum. The NMR data showed a lowfield position of C-2 of the $\beta$-D-glucuronic acid unit $\left(\delta_{\mathrm{C}} 80.2\right)$ indicating it to be substituted at this position. The sugar units with anomeric protons at $\delta_{\mathrm{H}} 5.37(\mathrm{~d}, J=8.1 \mathrm{~Hz}), 4.36(\mathrm{~d}, J=7.8 \mathrm{~Hz})$ and $4.71(\mathrm{~d}, J=7.7 \mathrm{~Hz})$ corresponded to three $\beta$-D-glucopyranose units (glc, glc and glc", respectively), characterized by the large coupling constants $\left(J_{\mathrm{H}-1, \mathrm{H}-2}, J_{\mathrm{H}-2, \mathrm{H}-3}, J_{\mathrm{H}-3, \mathrm{H}-4}\right.$, and $J_{\mathrm{H}-}$ 
4,H-5 $\geq 7.7 \mathrm{~Hz})$ as summarized in Table 6 . The rOe interactions observed in the ROESY spectrum between H-1, H-3 and H-5 of D-glucuronic acid and D-glucose units confirmed the $\alpha$-axial orientation of these protons and the $\beta$-anomeric configuration. The ${ }^{1} \mathrm{H}$ - and ${ }^{13} \mathrm{C}-\mathrm{NMR}$ spectra of 7 displayed many similarities with those of giganteoside M (3- $O$-[ $\beta$-Dgalactopyranosyl-( $1 \rightarrow 2)$ - $\beta$-D-glucuronopyranosyl]-28- $O$-[ $\beta$-D-glucopyranosyl-( $1 \rightarrow 6)-\beta$-D-

glucopyranosyl]-hederagenin) (Tabatadze et al., 2007), especially for the resonances assigned to hederagenin, $\beta$-D-glucuronopyranosyl (glcA) and two $\beta$-D-glucopyranose units (glc and $\left.\mathrm{glc}^{\prime}\right)$. The difference was the nature of sugar residue attached to the $\mathrm{C}-2$ of $\mathrm{glcA} ; \beta$-Dglucopyranose in 7 and $\beta$-D-galactopyranose in giganteoside $\mathrm{M}$. In the HMBC spectrum of 7, cross-peaks were observed between $\mathrm{glc}^{\prime \prime}-\mathrm{H}-1 / \mathrm{glcA}-\mathrm{C}-2\left(\delta_{\mathrm{C}-2} 80.2\right)$, glcA-H-1/aglycone-C-3 $\left(\delta_{\mathrm{C}-3} \quad 82.3\right)$, glc'-H-1/glc-C-6 $\left(\delta_{\mathrm{C}-6} \quad 68.1\right)$ and glc-H-1/aglycone-C-28 $\left(\delta_{\mathrm{C}-28} 175.7\right)$. These evidences led to the assignment of 7 as $3-O-[\beta$-D-glucopyranosyl-( $1 \rightarrow 2)-\beta$-D-

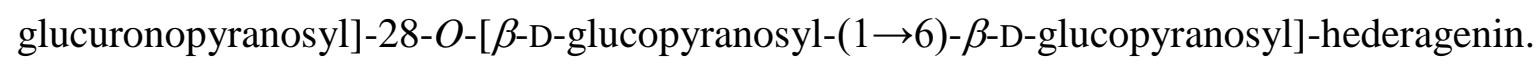

The HRESIMS spectrum of scabiostellatoside $H(8)$ exhibited an ion at $\mathrm{m} / \mathrm{z} \quad 995.4836$ $[\mathrm{M}+\mathrm{Na}]^{+}$, which was in accordance with the molecular formula of $\mathrm{C}_{48} \mathrm{H}_{76} \mathrm{O}_{20}$ (calcd 955.4828, $\mathrm{C}_{48} \mathrm{H}_{76} \mathrm{O}_{20} \mathrm{Na}$ ). The ${ }^{1} \mathrm{H}$ - and/or ${ }^{13} \mathrm{C}-\mathrm{NMR}$ spectra of $\mathbf{8}$ exhibited signals for a double bond $\left[\delta_{\mathrm{H}} / \delta_{\mathrm{C}} 5.27(\mathrm{t}, J=3.4 \mathrm{~Hz}) / 125.7(\mathrm{C}-12) ; 137.1(\mathrm{C}-13)\right]$, four tertiary methyls $\left[\delta_{\mathrm{H}} / \delta_{\mathrm{C}} 0.78\right.$ (s)/13.6 ( $\left.\left.\mathrm{CH}_{3}-24\right) ; 1.07(\mathrm{~s}) / 16.5\left(\mathrm{CH}_{3}-25\right) ; 0.87(\mathrm{~s}) / 16.4\left(\mathrm{CH}_{3}-26\right) ; 1.15(\mathrm{~s}) / 22.6\left(\mathrm{CH}_{3}-27\right)\right]$, two secondary methyls $\left[\delta_{\mathrm{H}} / \delta_{\mathrm{C}} 0.92(\mathrm{~d}, J=6.3 \mathrm{~Hz}) / 16.2\left(\mathrm{CH}_{3}-29\right) ; 0.99(\mathrm{~d}, J=6.3 \mathrm{~Hz}) / 20.1\right.$ $\left.\left(\mathrm{CH}_{3}-30\right)\right]$, two oxymethines $\left[\delta_{\mathrm{H}} / \delta_{\mathrm{C}} 3.54(\mathrm{~d}, J=9.5 \mathrm{~Hz}) / 86.1(\mathrm{CH}-3) ; 3.82(\mathrm{~m}) / 66.4(\mathrm{CH}-2)\right]$, a hydroxymethylene $\left[\delta_{\mathrm{H}} / \delta_{\mathrm{C}} 3.30(\mathrm{~d}, J=11.8 \mathrm{~Hz}), 3.70(\mathrm{~d}, J=11.8 \mathrm{~Hz}) / 62.5\left(\mathrm{CH}_{2}-23\right)\right]$, a methine $\left[\delta_{\mathrm{H}} / \delta_{\mathrm{C}} 2.26(\mathrm{~d}, J=11.4 \mathrm{~Hz}) / 52.8(\mathrm{CH}-18)\right]$ and an ester carbonyl [ $\left.\delta_{\mathrm{C}} 176.7(\mathrm{C}-28)\right]$, characteristic of an urs-12-en-28-oic-acid derivative (Table 5), which was trihydroxylated in positions $\mathrm{C}-2 \alpha, \mathrm{C}-3 \beta$ and $\mathrm{C}-23$, as in asiatic acid (Acebey-Castellon et al., 2011). The large coupling constant between the vicinal diol H-2 and $\mathrm{H}-3\left(J_{\mathrm{H}-2, \mathrm{H}-3}=9.5 \mathrm{~Hz}\right)$ indicated that the 
two protons adopted a quasi trans-diaxial relationship. The location of the primary hydroxyl group $\left(\delta_{\mathrm{H}} 3.30\right.$ and 3.70 , each $\mathrm{d}, J=11.8 \mathrm{~Hz}$ ) at $\mathrm{C}-23$ was deduced from the chemical shift of C-24 at $\delta$ C 13.6 characteristic of an axial position, and by comparison of the ${ }^{13} \mathrm{C}$ NMR spectrum with that of asiatic acid. The $\alpha$-equatorial orientation of $\mathrm{H}_{3}-23$ was confirmed by the correlations observed in the ROESY spectrum between $\mathrm{H}_{3}-23$ and $\mathrm{H}-3$ and $\mathrm{H}-5$ and between H-3/H-5 and H-5/H-9 $\alpha$-axial oriented. In the same manner, the ROESY correlations observed between $\mathrm{H}-2 / \mathrm{H}_{3}-24, \mathrm{H}_{3}-25$ and between $\mathrm{H}_{3}-25 / \mathrm{H}-26$, confirmed the $\beta$-axial orientation of these $\mathrm{CH}_{3}$ and $\mathrm{H}-2$. The assignments of other proton and carbon signals of the aglycone were accomplished by analysis of the usual 2D COSY, ROESY, HSQC and HMBC experiments (Table 5). The ${ }^{1} \mathrm{H}$ and ${ }^{13} \mathrm{C}$ NMR values were in full agreement with those reported in the literature for asiatic acid (Acebey-Castellon et al., 2011). Further analysis of the ${ }^{1} \mathrm{H}$ and ${ }^{13} \mathrm{C}$ NMR spectra of 8 revealed the presence of three anomeric protons at $\delta_{\mathrm{H}} 4.55$, 5.34 and 5.37 correlated in the HSQC spectrum with three anomeric carbons at $\delta 102.4,101.0$ and 94.3, respectively (Table 6). Complete assignment of each glycoside proton system was achieved by analysis of 2D-NMR experiments. A $\beta$-D-glucopyranose unit (glc) was identified starting from the anomeric proton at $\delta_{\mathrm{H}} 5.37(\mathrm{~d}, J=8.1 \mathrm{~Hz})$. The second monosaccharide whose anomeric proton resonates at $\delta 4.55(\mathrm{~d}, J=7.5 \mathrm{~Hz})$ was identified as a $\beta$-D-glucuronic acid (glcA), as in compound 7 , characterized by its $\mathrm{H}-5\left(\delta_{\mathrm{H}} 3.64, \mathrm{~d} J=9.4 \mathrm{~Hz}\right)$ and the carbonyl C-6 at $\delta_{\mathrm{C}} 176.5$ (Table 6). The third sugar unit was identified as terminal $\alpha$-Lrhamnopyranose (rha), as in compounds 1 and $\mathbf{2}$ (Tables 2 and 6). In the HMBC experiment, the cross-peaks observed between rha-H-1/glcA-C-2 $\left(\delta_{\mathrm{C}-2} 78.0\right)$, glcA-H-1/aglycone-C-3 $\left(\delta_{\mathrm{C}-3}\right.$ 86.1) and glc-H-1/aglycone-C-28 ( $\left.\delta_{\mathrm{C}-28} 176.7\right)$ led to the assignment of compound $\mathbf{8}$ as $3-O-$ [ $\alpha$-L-rhamnopyranosyl-( $1 \rightarrow 2)$ - $\beta$-D-glucuronopyranosyl]-28- $O$-[ $\beta$-D-glucopyranosyl]-asiatic acid. 
Compounds 1-8 were evaluated for their cytotoxicity against fibrosarcoma cell line (HT1080) by using the metabolic WST1 cell viability assay (Lehbili et al., 2017). Among the tested compounds, the monodesmoside $\mathbf{6}$ exhibited an interesting antiproliferative effect at lower concentration $\left(\mathrm{IC}_{50} 12.0 \pm 0.2 \mu \mathrm{M}\right.$ ). The bidesmosides $\mathbf{2}, \mathbf{4}$ and $\mathbf{5}$ were less active $\left(\mathrm{IC}_{50} 49.0 \pm\right.$ $0.7,40.0 \pm 0.7$ and $38.0 \pm 0.8 \mu \mathrm{M}$, respectively). The asiatic acid derivative (8) exhibited also moderate cytotoxicity ( $\mathrm{IC}_{50} 40 \pm 0.8 \mu \mathrm{M}$ ). Compounds $\mathbf{1}, \mathbf{3}$ and $\mathbf{7}$ were not active at the concentration of $50 \mu \mathrm{M}$. Comparison of results of active compounds $\mathbf{2}$ and $\mathbf{4}$ with this of $\mathbf{1}$ and $\mathbf{3}$ suggested that the cytotoxic activity may be related to the nature of the sugar residue attached at C-3 of the aglycone; xylose in $\mathbf{2}$ and $\mathbf{4}$ and arabinose in $\mathbf{1}$ and $\mathbf{3}$. Comparison of values of compounds $\mathbf{3}$ and $\mathbf{5}$ with arabinose attached to C-3 of aglycone suggested that the presence of a ramified sugar chain in $\mathbf{5}\left(\mathrm{IC}_{50} 38.0 \pm 0.8 \mu \mathrm{M}\right)$ is more favorable to cytotoxic activity than a linear chain in $\mathbf{3}$.

In summary, eleven structurally diverse compounds were isolated and identified from $70 \%$ EtOH crude extract of Scabiosa stellata, among them eight triterpenoid saponins were previously undescribed and their cytotoxic activity against fibrosarcoma cell line (HT1080) were evaluated. Compounds 1-6 are glycosides of oleanolic acid, compounds $\mathbf{7}$ and $\mathbf{9}$ are bidesmosides of hederagenin with glucuronic acid linked to $\mathrm{C}-3$ of aglycone, and $\mathbf{8}$ is a bidesmoside of ursolic acid. Comparison of compounds 1-9 with saponins previously identified in Scabiosa species indicated that oleanolic saponins (1-5) were similar to Scabiosaponins A-K and hookeroside A isolated from S. tshiliensis (Zheng et al, 2004) with a gentiobiose attached to the aglycone in C-28. The presence of a glucuronic acid linked to C-3 of aglycone (compounds 7-9) was observed for the first time in Scabiosa saponins in witch xylose or arabinose unit was generally linked to C-3 as in compounds 1-6 and in scabrioside A-D (Baykal 1999, Baykal et al., 1997, Baykal et al., 1998), songoroside A (Akimaliev et al., 
1988), songoroside C, G, I, M and O (Akimaliev et al., 1976). The monodesmoside 6 exhibited an interesting antiproliferative effect at lower concentration.

\section{Experimental}

\subsection{General experimental procedures}

Optical rotations were measured on a Perkin Elmer model 341 polarimeter $\left(589 \mathrm{~nm}, 20^{\circ} \mathrm{C}\right)$. ${ }^{1} \mathrm{H}-,{ }^{13} \mathrm{C}-\mathrm{NMR}$ and $2 \mathrm{D}-\mathrm{NMR}$ measurements were recorded in $\mathrm{CD}_{3} \mathrm{OD}$ on a Bruker Avance III 500 spectrometer $\left({ }^{1} \mathrm{H}\right.$ at $500 \mathrm{MHz}$ and ${ }^{13} \mathrm{C}$ at $\left.125 \mathrm{MHz}\right)$ or on a Bruker Avance AVIII-600 spectrometer $\left({ }^{1} \mathrm{H}\right.$ at $600 \mathrm{MHz}$ and ${ }^{13} \mathrm{C}$ at $\left.150 \mathrm{MHz}\right)$ equipped with a $5 \mathrm{~mm}$ TCI cryoprobe. 2D-NMR experiments were performed using standard Bruker microprograms (TopSpin 3.2 software). Exact masses were measured on a Micromass Q-TOF (Manchester, UK) highresolution mass spectrometer. Mass spectra were recorded in the positive-ion mode in the range $m / z 100-2000$, with a mass resolution of 20000 and an acceleration voltage of $0.7 \mathrm{kV}$. CC was carried out on HP-20 resin (Sigma Aldrich). Flash chromatography was carried out on a Grace Reveleris system equipped with dual UV and ELSD detection using Grace® cartridges (Silica gel or RP-C 18 ). HPLC separations were performed on a Dionex apparatus equipped with an ASI-100 autosampler, an Ultimate 3000 pump, a STH 585 column oven, a diode array detector UVD $340 \mathrm{~S}$ and a Chromeleon software. A prepacked RP-C 18 column (Phenomenex $250 \times 15 \mathrm{~mm}$, Luna $5 \mu$ ) was used for semi-preparative HPLC. The eluting mobile phase consisted of $\mathrm{H}_{2} \mathrm{O}$ with TFA $(0.0025 \%)$ and $\mathrm{CH}_{3} \mathrm{CN}$ with a flow rate of 5 $\mathrm{mL} / \mathrm{min}$ and the chromatogram was monitored at 205 and $210 \mathrm{~nm}$. Thin-layer chromatographies (TLC) were carried out using silica gel $60 \mathrm{~F}_{254}$ pre-coated aluminium plates (0.2 mm, Merck). After developing with solvent systems, TLC were sprayed with $50 \% \mathrm{H}_{2} \mathrm{SO}_{4}$ followed by heating.

\subsection{Plant material}


The whole plant Scabiosa stellata Cav. was collected in June 2015 from Constantine (North eastern of Algeria). The plant was identified by Kamel Kabouche and a voucher specimen (LOST.Cs.06.15) has been deposited at the University of Constantine, Algeria.

\subsection{Extraction and isolation}

The dried and powdred S. stellata whole plant $(653 \mathrm{~g})$ was macerated in $70 \% \mathrm{EtOH}(3 \times 3 \mathrm{~L}$, 24h) at room temperature. After filtration and concentration under low pressure, the $70 \%$ EtOH extract (118 g) was separated on a Diaion HP-20 resin column $(4.3 \times 40 \mathrm{~cm})$, eluted with $\mathrm{H}_{2} \mathrm{O}-\mathrm{MeOH}(0,25,50,75$ and $100 \%$, each $2 \mathrm{~L})$, to give fractions A-E, respectively. Fraction D (8.3 g) was fractionated by flash chromatography over silica gel, eluted by a gradient system of $\mathrm{CHCl}_{3}-\mathrm{MeOH}-\mathrm{H}_{2} \mathrm{O}$ (10:0:0 to 4:6:0.5), in 35 min to afford 40 subfractions $\left(\mathrm{f}_{1}-\mathrm{f}_{40}\right)$. Fraction $\mathrm{f}_{31}(300 \mathrm{mg})$ was submitted to a flash chromatography over RP-C 18 , eluted by a gradient system of $18-60 \% \mathrm{CH}_{3} \mathrm{CN}$, in 32 min to afford compound 1 (4.5mg). Fraction $\mathrm{f}_{33}(105 \mathrm{mg})$ was purified by semi-prep. HPLC using a gradient from $25 \%$ to $35 \%$ $\mathrm{CH}_{3} \mathrm{CN}$ in $10 \mathrm{~min}$, then isocratic elution at $35 \% \mathrm{CH}_{3} \mathrm{CN}$ for $20 \mathrm{~min}$ to yield $7 \mathrm{mg}$ of compound $2\left(t_{R} 21.9\right)$. Fraction $\mathrm{f}_{34}(154 \mathrm{mg})$ was purified by flash chromatography over RP$\mathrm{C}_{18}$, eluted with $\mathrm{MeOH}: \mathrm{H}_{2} \mathrm{O}$ (30\% to $100 \%$, in $30 \mathrm{~min}$ ) to yield $4 \mathrm{mg}$ of compound $\mathbf{8}$. The purification by semi-prep. HPLC of subfractions $36-38$ obtained from $\mathrm{f}_{34}$ led to compounds 3 $\left(t_{R} 11.5,7 \mathrm{mg}\right)$ and $4\left(t_{R} 12.6,8 \mathrm{mg}\right)$ (isocratic elution with $\left.35 \% \mathrm{CH}_{3} \mathrm{CN}\right)$. Fraction $\mathrm{f}_{35}(150$ mg) was subjected to flash chromatography over $\mathrm{RP}_{-} \mathrm{C}_{18}$, eluted with $\mathrm{MeOH}: \mathrm{H}_{2} \mathrm{O}$ (10\% to $60 \%$, in $30 \mathrm{~min})$ to yield compounds $5(5 \mathrm{mg}), \mathbf{6}(3 \mathrm{mg})$ and $9(3 \mathrm{mg})$. Fraction $\mathrm{f}_{36}(500 \mathrm{mg})$ was purified by flash chromatography over $\mathrm{RP}-\mathrm{C}_{18}$, eluted with $\mathrm{MeOH}: \mathrm{H}_{2} \mathrm{O}$ (10\% to $60 \%$, in $30 \mathrm{~min}$ ) to give compound 7 (4 mg). Fraction $\mathrm{E}$ was submitted to flash chromatography over silica gel, eluted by a gradient system of $\mathrm{CHCl}_{3}-\mathrm{MeOH}$ (10:0 to 4:6), in 32 min to afford $\mathbf{1 0}$ (15 mg) and $11(18 \mathrm{mg})$.

\subsection{Acid hydrolysis}


Acid hydrolysis was carried out to obtain the sugar residues of compounds 1-8. An aliquot of the saponin mixture (100 mg of fraction D of the Diaion HP-20 resin chromatography) was treated with $2 \mathrm{~N}$ TFA (trifluoroacetic acid, aqueous solution, $15 \mathrm{~mL}$ ) at $90{ }^{\circ} \mathrm{C}$ for $6 \mathrm{~h}$. After extraction with $\mathrm{CH}_{2} \mathrm{Cl}_{2}(10 \mathrm{~mL} \times 3)$, the water-soluble layer was evaporated to dryness. The sample $\left(55 \mathrm{mg}\right.$ ) was purified by preparative Si gel TLC (MeCOEt:iso-PrOH: $\mathrm{Me}_{2} \mathrm{CO}: \mathrm{H}_{2} \mathrm{O}$, 20:10:7:6)) to afford rhamnose [2.5 $\left.\mathrm{mg}, R_{\mathrm{f}}=0.73,[\alpha]^{20}{ }_{\mathrm{D}}+11\left(c 0.21, \mathrm{H}_{2} \mathrm{O}\right)\right]$; arabinose [2 mg, $\left.R_{\mathrm{f}}=0.59,[\alpha]^{20}{ }_{\mathrm{D}}+43\left(c 0.17, \mathrm{H}_{2} \mathrm{O}\right)\right] ;$ xylose $\left[1.9 \mathrm{mg}, R_{\mathrm{f}}=0.52,[\alpha]^{20}{ }_{\mathrm{D}}+18\left(c 0.2, \mathrm{H}_{2} \mathrm{O}\right)\right] ;$ glucose [4 mg, $\left.R_{\mathrm{f}}=0.48,[\alpha]_{\mathrm{D}}^{20}+30\left(c 0.33, \mathrm{H}_{2} \mathrm{O}\right)\right]$ and glucuronic acid $\left[0.9 \mathrm{mg}, R_{\mathrm{f}}=0.1\right.$, $\left.[\alpha]^{20}+29.2\left(c 0.08, \mathrm{H}_{2} \mathrm{O}\right)\right]$.

\subsection{Cell proliferation assay}

The fibrosarcoma cells (HT1080) were cultured in Minimum Essential Media (MEM) supplemented with $10 \%$ fetal bovine serum (FBS) and 1\% Penicillin Streptomycin (PS) at 37 ${ }^{\circ} \mathrm{C}$ with $5 \% \mathrm{CO}_{2}$ and harvested every three days for maintenance. Compounds $\mathbf{1 - 8}$ were dissolved in DMSO. For treatment, cells were plated at a density of $10^{4}$ cells $/ \mathrm{mL}$ in 24 -well plates at $37^{\circ} \mathrm{C}$. After $24 \mathrm{~h}$, the culture medium was discarded and cells were treated with the compounds in a fresh culture medium at various concentrations for $72 \mathrm{~h}$, while the same dilution volume of DMSO was added in negative control wells. The concentration of DMSO did not exceed $0.1 \%$ to avoid significant toxicity on the tested cells. Therefore, the cells were washed once with $1 \mathrm{~mL}$ of D-PBS and then detached with $0.2 \%$ Trypsin/EDTA. Cell counting was carried out on a KOVA® slide and with a phase contrast microscope as indicated by the manufacturer. Cell growth was calculated in percentage as the fraction of cell number in treated and control cells. $\mathrm{IC}_{50}$ was determined as the concentration of each compound which induced $50 \%$ inhibition of cell growth. The values represent averages of three independent experiments. Doxorubicin was used as a positive control agent. 
3.6. Scabiostellatoside $\boldsymbol{A}(1)$ : amorphous, white powder; $[\alpha]^{20} \mathrm{D}-20.8(c 0.35, \mathrm{MeOH}) ;{ }^{1} \mathrm{H}$ $\left(500 \mathrm{MHz}, \mathrm{CD}_{3} \mathrm{OD}\right)$ and ${ }^{13} \mathrm{C} \mathrm{NMR}\left(125 \mathrm{MHz}, \mathrm{CD}_{3} \mathrm{OD}\right)$ data, see tables 1 and 2; HRESIMS $m / z 1359.6552\left(\right.$ calcd for $\left.\mathrm{C}_{64} \mathrm{H}_{104} \mathrm{O}_{29} \mathrm{Na}, 1359.6561\right)$.

3.8. Scabiostellatoside B (2): amorphous, white powder; $[\alpha]^{20} \mathrm{D}-25(c 0.20, \mathrm{MeOH}) ;{ }^{1} \mathrm{H}(500$ $\mathrm{MHz}, \mathrm{CD}_{3} \mathrm{OD}$ ) and ${ }^{13} \mathrm{C}$ NMR (125 MHz, CD $\left.{ }_{3} \mathrm{OD}\right)$ data, see tables 3 and 4; HRESIMS $\mathrm{m} / \mathrm{z}$ 1359.6548 (calcd for $\mathrm{C}_{64} \mathrm{H}_{104} \mathrm{O}_{29} \mathrm{Na}, 1359.6561$ ).

3.9. Scabiostellatoside $\boldsymbol{C}$ (3): amorphous, white powder; $[\alpha]^{20} \mathrm{D}-27.8(c 0.18, \mathrm{MeOH}) ;{ }^{1} \mathrm{H}$ (600 MHz, CD $\left.{ }_{3} \mathrm{OD}\right)$ and ${ }^{13} \mathrm{C} \mathrm{NMR}\left(150 \mathrm{MHz}, \mathrm{CD}_{3} \mathrm{OD}\right)$ data, see tables 1 and 2; HRESIMS $m / z 1521.7097$ (calcd for $\mathrm{C}_{70} \mathrm{H}_{114} \mathrm{O}_{34} \mathrm{Na}, 1521.7089$ ).

3.10. Scabiostellatoside $\boldsymbol{D}(4)$ : amorphous, white powder; $[\alpha]^{20} \mathrm{D}-24.3(c 0.28, \mathrm{MeOH}) ;{ }^{1} \mathrm{H}$ (500 MHz, $\left.\mathrm{CD}_{3} \mathrm{OD}\right)$ and ${ }^{13} \mathrm{C} \mathrm{NMR}\left(125 \mathrm{MHz}, \mathrm{CD}_{3} \mathrm{OD}\right)$ data, see tables 3 and 4; HRESIMS $m / z 1521.7096$ (calcd for $\left.\mathrm{C}_{70} \mathrm{H}_{114} \mathrm{O}_{34} \mathrm{Na}, 1521.7089\right)$.

3.11. Scabiostellatoside $\boldsymbol{E}$ (5): amorphous, white powder; $[\alpha]^{20} \mathrm{D}-26(c 0.26, \mathrm{MeOH}) ;{ }^{1} \mathrm{H}$ (500 MHz, $\left.\mathrm{CD}_{3} \mathrm{OD}\right)$ and ${ }^{13} \mathrm{C} \mathrm{NMR}\left(125 \mathrm{MHz}, \mathrm{CD}_{3} \mathrm{OD}\right)$ data, see tables 1 and 2; HRESIMS $m / z 1521.7075$ (calcd for $\mathrm{C}_{70} \mathrm{H}_{114} \mathrm{O}_{34} \mathrm{Na}, 1521.7089$ ).

3.12. Scabiostellatoside $\boldsymbol{F}(6)$ : amorphous, white powder; $[\alpha]^{20} \mathrm{D}-10(c 0.1, \mathrm{MeOH}) ;{ }^{1} \mathrm{H}(600$ $\mathrm{MHz}, \mathrm{CD}_{3} \mathrm{OD}$ ) and ${ }^{13} \mathrm{C} \mathrm{NMR}\left(150 \mathrm{MHz}, \mathrm{CD}_{3} \mathrm{OD}\right)$ data, see tables 3 and 4; HRESIMS $\mathrm{m} / \mathrm{z}$ 1521.7080 (calcd for $\mathrm{C}_{70} \mathrm{H}_{114} \mathrm{O}_{34} \mathrm{Na}, 1521.7089$ ).

3.13. Scabiostellatoside $\boldsymbol{G}(7)$ : amorphous, white powder; $[\alpha]^{20} \mathrm{D}-11.8^{\circ}(c 0.28, \mathrm{MeOH}) ;{ }^{1} \mathrm{H}$ (500 MHz, CD 3 OD) and ${ }^{13} \mathrm{C}$ NMR (125 MHz, CD 3 OD) data, see tables 5 and 6; HRESIMS $m / z 1157.5363$ (calcd for $\mathrm{C}_{54} \mathrm{H}_{86} \mathrm{O}_{25} \mathrm{Na}, 1157.5356$ ).

3.14. Scabiostellatoside $\boldsymbol{H}(8)$ : amorphous, white powder; $[\alpha]^{20} \mathrm{D}-20^{\circ}(c 0.21, \mathrm{MeOH}) ;{ }^{1} \mathrm{H}$ (500 MHz, CD 3 OD) and ${ }^{13} \mathrm{C}$ NMR (125 MHz, CD 3 OD) data, see tables 5 and 6; HRESIMS $m / z 995.4836$ (calcd 955.4828, $\mathrm{C}_{48} \mathrm{H}_{76} \mathrm{O}_{20} \mathrm{Na}$ ).

\section{Supporting Information}


HRESIMS and 1D- and 2D-NMR spectra of compounds 1-8.

\section{Acknowledgements}

The authors are grateful to MESRS Algeria for the PNE grant to Ms Meryem Lehbili, to CNRS, CRCA, Conseil Général de la Marne, MESR in France, and to the PIANET CPER project for financial support.

\section{References}

Akimaliev, A.; Alimbaeva, P. K.; Mzhel'skaya, L. G.; Abubakirov, N. K. 1976. Triterpene glycosides of Scabiosa soongorica. III. Structure of songorosides M and O. Khim. Prir.Soedin. (4), 476-479.

Akimaliev, A.; Alimbaeva, P. K.; Mzhel'skaya, L. G.; Abubakirov, N. K. 1976. Triterpene glycosides of Scabiosa soongorica. II. Structure of songorosides C, G, and I. Khim. Prir.Soedin. (4), 472-476

Akimaliev, A. A.; Putieva, Zh. M.; Alimbaeva, P. K.; Abubakirov, N. K. 1988.Triterpene glycosides of Scabiosa soongorica. V. $\beta$-Sitosterol $\beta$-D-glucopyranoside and soongoroside A. Khim. Prir.Soedin. (6), 885-886.

Alabdul Magid, A., Morjani, H., Madoulet, C., Dumontet, V., Lavaud, C., 2015. Triterpenoid glycosides from the leaves of Meliosma henryi. Phytochemistry 109, 49-56.

Alabdul Magid, A., Voutquenne, L., Moretti, C., Long, C., Lavaud, C., 2006. Triterpenoid Saponins from the Fruits of Caryocar glabrum. J Nat Prod. 69,196-205.

Alimbaeva, P. K.; Akimaliev, A.; Mukhamedziev, M. M. 1977. Triterpene glycosides of some representatives of the Dipsacaceae family. Khim. Prir.Soedin. (5), 708-709.

Acebey-Castellon, L., Voutquenne-Nazabadioko, L., Doan Thi Mai, H., Roseau, N., Bonet, M.A., Vallès, J., 2007. Ethnobotany of Montseny biosphere reserve (Catalonia, Iberian Peninsula): Plants used in veterinary medicine. J Ethnopharmacol 110:130-47. 
Baykal, T. 1999. Two monodesmosidic triterpenoid saponins from Scabiosa rotata Bieb. J. Fac. Pharm. Gazi Univ. 16(1), 1-6.

Baykal, T., Panayir, T., Sticher, O., Çalis I., 1997. Scabioside A: a new triterpenoid saponoside from Scabiosa rotata. J. Fac. Pharm. Gazi Univ. 14(1), 31-36.

Baykal, T., Panayir, T., Tasdemir, D., Sticher, O., Çalis I., 1998. Triterpene saponins from Scabiosa rotata. Phytochemistry 48, 867-873.

Bammi., J.; Douira., A., 2002. Medicinal plants in the forest of Achach (central plateau, Morocco). J Acta Bot Mal. 27, 131-145.

Carlson, S.E.; Linder, H.P.; Donoghue, M.J., 2012. The historical biogeography of Scabiosa (Dipsacaceae): implications for Old World plant disjunctions. J Biogeogr. 39, 1086-1100.

Chang, X.L., Li, W., Jia, Z.H., Satou, T., Fushiya, S., Koike, K., 2007. J Nat Prod. 70, 179187.

Christopoulou, C., Graikou, K.,Chinou, I., 2008. Chemosystematic value of chemical constituents from Scabiosa hymettia (Dipsacaceae). Chem Biodivers. 2, 318-323.

Garaev, E. A., Movsumov, I.S., Isaev, M.I., 2008. Flavonoids and oleanolic acid from Scabiosa caucasia. Chem Nat Compd. 44, 520-521.

Mahato, S.B., Kundo, A.P., 1994. ${ }^{13} \mathrm{C}$ NMR spectra of pentacyclic triterpenoids - A compilation and some salient features. Phytochemistry, 37, 1517-1575.

Lehbili, M., Alabdul Magid, A., Kabouche, A., Voutquenne-Nazabadioko, L., Abedini A., Morjani, H., Sarazin, T., Gangloff, S.C., Kabouche, Z., 2017. Oleanane-type triterpene saponins from Calendula stellata. Phytochemistry 144, 33-42.

Papalexandrou, A., Magiatis, P., Perdetzoglou, D., Skaltsounis, A.L., Chinou, I.B., Harvala, C., 2003. Iridoids from Scabiosa variifolia (Dipsacaceae) growing in Greece. Biochem Syst Ecol. 31, 91-93. 
Polat, E., Alankus-Caliskan, Ö., Karayildirim T., Bedir, E., 2010. Iridoids from Scabiosa atropurpurea L. subsp. maritima Arc. (L.). Biochem Syst Ecol. 38, 253-255.

Pottier-Alapetite, G., 1981. Flore of Tunisia. Angiosperms-dicotyledons-gamopetals. Tunis: Ed. Ministère de l'Enseignement Supérieur et de la Recherche Scientifique et le Ministère de l'Agriculture, pp 926.

Quezel P., Santa S., 1963. New flora of Algeria and the desert regions Meridional. Tome II. Paris : Ed. French National Center for Scientific Research, pp 890-893.

Rahmouni, N., Pinto, D.C.G.A., Santos, S.A.O., Beghidja, N., Silva, A.M.S., 2017. Lipophilic composition of Scabiosa stellata L.: an underexplored plant from Batna (Algeria). Chem Papers. DOI: https://doi.org/10.1007/s11696-017-0308-3.

Tabatadze, N.; Elias, R.; Faure, R.; Gerkens, P.; De Pauw-Gillet, M.C.; Kemertelidze, E.; Chea A.; Olivier, E., 2007. Cytotoxic triterpenoid saponins from the roots of Cephalaria gigantea. Chem Pharm Bull. 55, 102-105.

Udayama, M., Ohkawa, M., Yoshida, N., Kinjo, J., Nohara, T., 1998. Structures of three new oleanene glucuronides isolated from Lathyrus palustris var. pilosus and hepatoprotective activity. Chem Pharm Bull. 46, 1412-1415.

Yusifova, J. Y.; Movsumov, I. S., 2015. Flavonoids and triterpenoid saponins of Scabiosa hyrcanica Stev., growing in Azerbaijan Khimiya Rastitel'nogo Syr'ya (2), 261-264

Zheng, Q., Koike, K., Han, L.K., Okuda, H., Nikaido, T., 2004. New biologically active triterpenoid saponins from Scabiosa tschiliensis. J Nat Prod. 67, 604-613. 


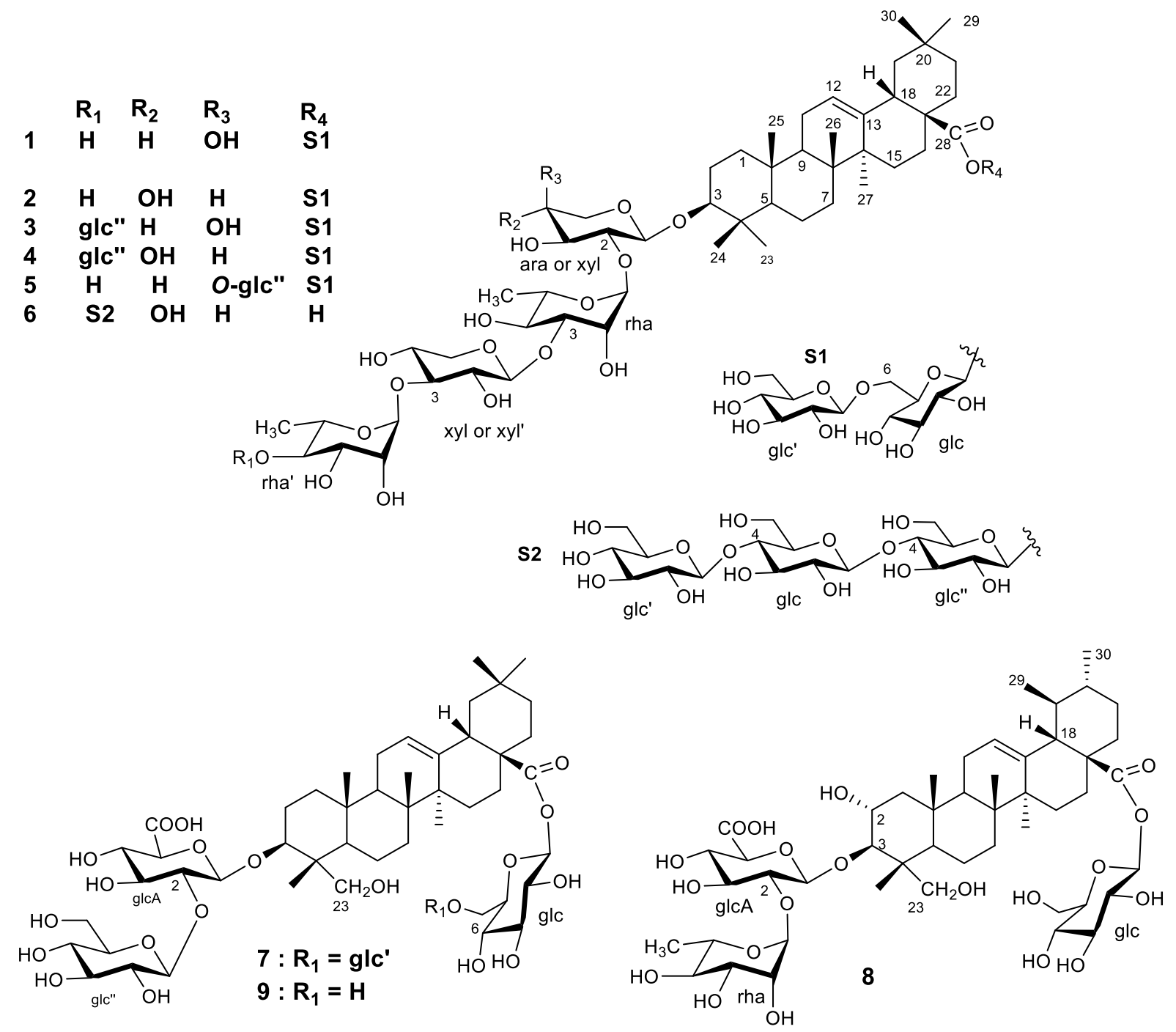

Figure 1. The structures of compounds 1-9 isolated from the whole plant Scabiosa stellata. 


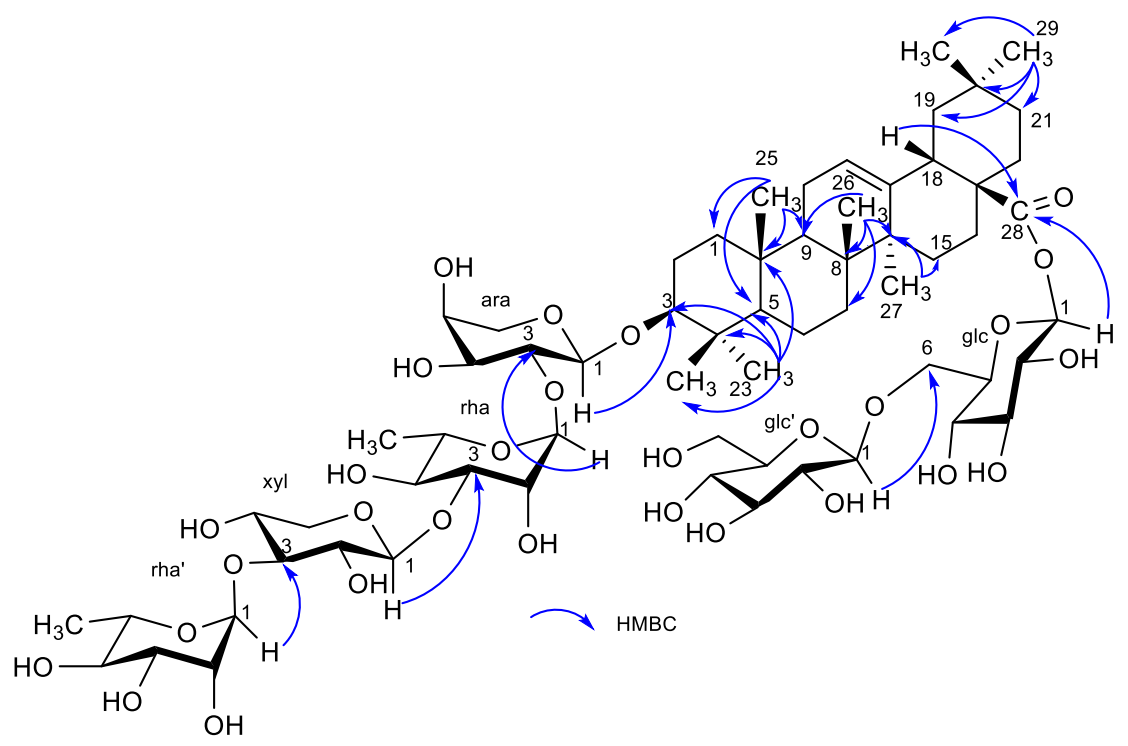

Figure 2. Key HMBC correlations for compound 1. 
Table 1. NMR spectroscopic data for the aglycone moieties for compounds $\mathbf{1}, \mathbf{5}\left(500 \mathrm{MHz}, \mathrm{CD}_{3} \mathrm{OD}\right)$ and $\mathbf{3}(600$ $\left.\mathrm{MHz}, \mathrm{CD}_{3} \mathrm{OD}\right)$.

\begin{tabular}{|c|c|c|c|c|c|c|}
\hline position & 1 & & 3 & & 5 & \\
\hline & $\delta_{\mathrm{H}} \mathrm{m}(J$ in $\mathrm{Hz})$ & $\delta_{\mathrm{C}}$ & $\delta_{\mathrm{H}} \mathrm{m}(J$ in $\mathrm{Hz})$ & $\delta_{\mathrm{C}}$ & $\delta_{\mathrm{H}} \mathrm{m}(J$ in $\mathrm{Hz})$ & $\delta_{\mathrm{C}}$ \\
\hline \multirow[t]{2}{*}{1} & $1.01 \mathrm{~m}$ & 38.6 & $1.01 \mathrm{~m}$ & 38.6 & $1.00 \mathrm{~m}$ & 38.5 \\
\hline & $1.65 \mathrm{~m}$ & & $1.65 \mathrm{dt}(13.6,3.5)$ & & $1.64 \mathrm{dt}(12.7,2.5)$ & \\
\hline \multirow[t]{2}{*}{2} & $1.73 \mathrm{~m}$ & 25.7 & $1.74 \mathrm{~m}$ & 25.7 & $1.73 \mathrm{~m}$ & 25.6 \\
\hline & $1.86 \mathrm{~m}$ & & $1.86 \mathrm{~m}$ & & $1.82 \mathrm{~m}$ & \\
\hline 3 & $3.15 \mathrm{dd}(11.6,4.2)$ & 89.2 & $3.14 \mathrm{dd}(11.6,4.3)$ & 89.2 & $3.14 \mathrm{dd}(11.7,4.4)$ & 89.1 \\
\hline 4 & - & 38.9 & - & 38.9 & - & 38.8 \\
\hline 5 & $0.81 \mathrm{~m}$ & 55.7 & $0.80 \mathrm{~m}$ & 55.7 & $0.80 \mathrm{~m}$ & 55.7 \\
\hline \multirow[t]{2}{*}{6} & $1.42 \operatorname{td}(13.7,3.5)$ & 18.0 & $1.44 \mathrm{~m}$ & 18.0 & $1.45 \operatorname{td}(13.9,3.8)$ & 17.9 \\
\hline & $1.57 \mathrm{~m}$ & & $1.57 \mathrm{~m}$ & & $1.57 \mathrm{~m}$ & \\
\hline \multirow[t]{2}{*}{7} & $1.33 \mathrm{~m}$ & 32.5 & $1.34 \mathrm{~m}$ & 32.5 & $1.33 \mathrm{~m}$ & 31.7 \\
\hline & $1.51 \mathrm{td}(13.1,3.5)$ & & $1.52 \operatorname{td}(12.7,3.3)$ & & $1.49 \mathrm{~m}$ & \\
\hline 8 & - & 39.3 & - & 39.3 & - & 39.2 \\
\hline 9 & $1.60 \mathrm{~m}$ & 47.7 & $1.60 \mathrm{~m}$ & 48.2 & $1.59 \mathrm{~m}$ & 47.6 \\
\hline 10 & - & 36.5 & - & 36.5 & - & 36.4 \\
\hline 11 & $1.92 \mathrm{~m}$ & 23.2 & $1.92 \mathrm{~m}$ & 23.4 & $1.90 \mathrm{~m}$ & 23.1 \\
\hline 12 & $5.27 \mathrm{t}(3.4)$ & 122.4 & $5.27 \mathrm{t}(3.4)$ & 122.3 & $5.27 \mathrm{t}(3.5)$ & 122.3 \\
\hline 13 & - & 143.5 & - & 143.5 & - & 143.4 \\
\hline 14 & - & 41.5 & - & 41.5 & - & 41.4 \\
\hline \multirow[t]{2}{*}{15} & $1.10 \mathrm{dt}(14.3,2.5)$ & 27.5 & $1.10 \mathrm{dt}(13.5,2.9)$ & 27.5 & $1.10 \mathrm{dt}(13.9,2.7)$ & 27.4 \\
\hline & $1.81 \mathrm{td}(14.3,4.4)$ & & $1.81 \mathrm{td}(14.0,3.7)$ & & $1.81 \mathrm{td}(13.9,3.9)$ & \\
\hline \multirow[t]{2}{*}{16} & $1.73 \mathrm{~m}$ & 22.6 & $1.73 \mathrm{~m}$ & 22.6 & $1.73 \mathrm{~m}$ & 22.5 \\
\hline & $2.08 \operatorname{td}(13.7,3.8)$ & & $2.07 \operatorname{td}(13.7,3.7)$ & & $2.07 \operatorname{td}(13.6,4.0)$ & \\
\hline 17 & - & 46.7 & - & 46.7 & - & 46.6 \\
\hline 18 & $2.86 \mathrm{dd}(13.9,3.8)$ & 41.2 & $2.88 \mathrm{dd}(13.5,4.0)$ & 41.2 & $2.88 \mathrm{dd}(13.7,4.4)$ & 41.1 \\
\hline \multirow[t]{2}{*}{19} & $1.17 \mathrm{~m}$ & 45.9 & $1.18 \mathrm{~m}$ & 45.8 & $1.16 \mathrm{~m}$ & 45.8 \\
\hline & $1.74 \mathrm{~m}$ & & $1.74 \mathrm{~m}$ & & $1.73 \mathrm{~m}$ & \\
\hline 20 & - & 30.1 & - & 30.1 & - & 30.0 \\
\hline \multirow[t]{2}{*}{21} & $1.25 \mathrm{~m}$ & 33.5 & $1.24 \mathrm{~m}$ & 33.5 & $1.24 \mathrm{~m}$ & 33.4 \\
\hline & $1.41 \operatorname{td}(14.1,4.1)$ & & $1.43 \operatorname{td}(13.8,3.7)$ & & $1.41 \mathrm{td}(13.9,3.8)$ & \\
\hline \multirow[t]{2}{*}{22} & $1.62 \mathrm{~m}$ & 31.8 & $1.62 \mathrm{~m}$ & 32.8 & $1.62 \mathrm{~m}$ & 32.1 \\
\hline & $1.73 \mathrm{~m}$ & & $1.74 \operatorname{td}(13.0,3.7)$ & & $1.73 \operatorname{td}(13.0,3.7)$ & \\
\hline 23 & $1.05 \mathrm{~s}$ & 27.2 & $1.04 \mathrm{~s}$ & 27.2 & $1.07 \mathrm{~s}$ & 27.1 \\
\hline 24 & $0.88 \mathrm{~s}$ & 15.8 & $0.88 \mathrm{~s}$ & 15.8 & $0.87 \mathrm{~s}$ & 15.7 \\
\hline 25 & $0.99 \mathrm{~s}$ & 14.8 & $0.98 \mathrm{~s}$ & 14.8 & $0.99 \mathrm{~s}$ & 14.7 \\
\hline 26 & $0.83 \mathrm{~s}$ & 16.6 & $0.83 \mathrm{~s}$ & 16.4 & $0.82 \mathrm{~s}$ & 16.3 \\
\hline 27 & $1.18 \mathrm{~s}$ & 24.9 & $1.18 \mathrm{~s}$ & 24.9 & $1.18 \mathrm{~s}$ & 24.8 \\
\hline 28 & - & 176.7 & - & 176.7 & - & 176.6 \\
\hline 29 & $0.93 \mathrm{~s}$ & 32.1 & $0.93 \mathrm{~s}$ & 32.1 & $0.93 \mathrm{~s}$ & 32.0 \\
\hline 30 & $0.97 \mathrm{~s}$ & 22.6 & $0.96 \mathrm{~s}$ & 22.6 & $0.96 \mathrm{~s}$ & 22.6 \\
\hline
\end{tabular}


Table 2. NMR spectroscopic data for the aglycone moieties for compounds $\mathbf{1}, \mathbf{5}\left(500 \mathrm{MHz}, \mathrm{CD}_{3} \mathrm{OD}\right)$ and $\mathbf{3}(600$ $\left.\mathrm{MHz}, \mathrm{CD}_{3} \mathrm{OD}\right)$.

\begin{tabular}{|c|c|c|c|c|c|c|}
\hline position & 1 & & 3 & & 5 & \\
\hline & $\delta_{\mathrm{H}} \mathrm{m}(J$ in $\mathrm{Hz})$ & $\delta_{\mathrm{C}}$ & $\delta_{\mathrm{H}} \mathrm{m}(J$ in $\mathrm{Hz})$ & $\delta_{\mathrm{C}}$ & $\delta_{\mathrm{H}} \mathrm{m}(J$ in $\mathrm{Hz})$ & $\delta_{\mathrm{C}}$ \\
\hline \multicolumn{7}{|l|}{ ara (at C-3) } \\
\hline 1 & $4.51 \mathrm{~d}(5.3)$ & 103.9 & $4.51 \mathrm{~d}(5.3)$ & 103.9 & $4.45 \mathrm{~d}(6.9)$ & 104.1 \\
\hline 2 & $3.78 \mathrm{dd}(7.1,5.3)$ & 75.0 & $3.78 \mathrm{dd}(7.1,5.3)$ & 74.9 & $3.75 \mathrm{dd}(7.8,6.9)$ & 75.2 \\
\hline 3 & $3.73 \mathrm{dd}(7.1,3.4)$ & 72.3 & $3.73 \mathrm{dd}(7.1,3.4)$ & 72.3 & $3.81 \mathrm{dd}(7.8,3.1)$ & 72.5 \\
\hline 4 & $3.79 \mathrm{~m}$ & 67.7 & $3.79 \mathrm{~m}$ & 67.7 & $3.92 \mathrm{~m}$ & 78.1 \\
\hline \multirow[t]{2}{*}{5} & $3.52 \mathrm{dd}(11.9,2.3)$ & 63.3 & 3.52 brd (12.4) & 63.3 & $3.57 \mathrm{~m}$ & 63.5 \\
\hline & $3.86 \mathrm{~m}$ & & $3.86 \mathrm{~m}$ & & $4.16 \mathrm{dd}(12.2,3.1)$ & \\
\hline \multicolumn{7}{|c|}{+2} \\
\hline 1 & $5.20 \mathrm{~d}(1.5)$ & 100.1 & $5.21 \mathrm{brs}$ & 100.1 & $5.26 \mathrm{~d}(1.8)$ & 99.9 \\
\hline 2 & $4.08 \mathrm{dd}(3.5,1.7)$ & 70.4 & $4.08 \mathrm{dd}(3.0,1.7)$ & 70.2 & $4.11 \mathrm{dd}(3.5,1.8)$ & 70.2 \\
\hline 3 & $3.85 \mathrm{dd}(9.5,3.5)$ & 80.6 & $3.85 \mathrm{dd}(9.5,3.0)$ & 80.6 & $3.88 \mathrm{dd}(9.6,3.5)$ & 80.5 \\
\hline 4 & $3.58 \mathrm{t}(9.5)$ & 71.4 & $3.58 \mathrm{t}(9.5)$ & 71.4 & $3.58 \mathrm{t}(9.6)$ & 71.3 \\
\hline 5 & $3.91 \mathrm{~m}$ & 68.6 & $3.91 \mathrm{~m}$ & 68.6 & $3.94 \mathrm{~m}$ & 68.5 \\
\hline 6 & $1.24 \mathrm{~d}(6.2)$ & 16.4 & $1.25 \mathrm{~d}(6.2)$ & 16.6 & $1.25 \mathrm{~d}(6.2)$ & 16.5 \\
\hline \multicolumn{7}{|l|}{ Xyl } \\
\hline 1 & $4.49 \mathrm{~d}(7.6)$ & 105.1 & $4.49 \mathrm{~d}(7.6)$ & 105.1 & $4.49 \mathrm{~d}(7.7)$ & 105.0 \\
\hline 2 & $3.40 \mathrm{dd}(8.1,7.6)$ & 74.4 & $3.40 \mathrm{dd}(8.8,7.6)$ & 74.5 & $3.41 \mathrm{dd}(8.9,7.7)$ & 74.3 \\
\hline 3 & $3.48 \mathrm{t}(8.1)$ & 82.1 & $3.48 \mathrm{t}(8.8)$ & 81.7 & 3.48 t (8.9) & 82.0 \\
\hline 4 & $3.55 \mathrm{~m}$ & 68.4 & $3.55 \mathrm{~m}$ & 68.3 & $3.55 \mathrm{~m}$ & 68.2 \\
\hline \multirow[t]{2}{*}{5} & $3.24 \mathrm{t}(11.4)$ & 65.7 & $3.24 \mathrm{dd}(11.0,9.2)$ & 65.7 & $3.24 \mathrm{t}(11.4)$ & 65.6 \\
\hline & $3.89 \mathrm{~m}$ & & $3.88 \mathrm{dd}(11.0,5.3)$ & & $3.90 \mathrm{dd}(12.1,5.1)$ & \\
\hline \multicolumn{7}{|l|}{ rha' } \\
\hline 1 & $5.19 \mathrm{~d}(1.4)$ & 101.1 & 5.19 brs & 100.8 & $5.19 \mathrm{~d}(1.6)$ & 101.0 \\
\hline 2 & $3.95 \mathrm{dd}(3.5,1.5)$ & 70.9 & $3.98 \mathrm{dd}(3.3,1.5)$ & 70.9 & $3.96 \mathrm{dd}(3.3,1.6)$ & 70.8 \\
\hline 3 & 3.72 dd $(9.7,3.5)$ & 70.8 & $3.97 \mathrm{dd}(9.2,3.3)$ & 70.8 & 3.73 dd $(9.3,3.3)$ & 70.7 \\
\hline 4 & $3.41 \mathrm{t}(9.7)$ & 72.6 & $3.64 \mathrm{t}(9.2)$ & 82.3 & $3.42 \mathrm{t}(9.3)$ & 72.5 \\
\hline 5 & $4.02 \mathrm{~m}$ & 68.6 & $4.13 \mathrm{~m}$ & 67.2 & $4.04 \mathrm{~m}$ & 68.5 \\
\hline 6 & $1.27 \mathrm{~d}(6.2)$ & 16.5 & $1.35 \mathrm{~d}(6.2)$ & 16.6 & $1.27 \mathrm{~d}(6.3)$ & 16.4 \\
\hline \multicolumn{7}{|l|}{ glc" } \\
\hline 1 & & & $4.61 \mathrm{~d}(7.6)$ & 104.3 & $4.47 \mathrm{~d}(7.6)$ & 104.6 \\
\hline 2 & & & $3.22 \mathrm{dd}(8.9,7.6)$ & 74.7 & $3.30 \mathrm{~m}$ & 73.8 \\
\hline 3 & & & 3.38 t (8.9) & 76.7 & $3.38 \mathrm{t}(8.9)$ & 76.6 \\
\hline 4 & & & $3.31 \mathrm{t}(8.9)$ & 70.1 & $3.29 \mathrm{t}(8.9)$ & 69.9 \\
\hline 5 & & & $3.27 \mathrm{~m}$ & 76.6 & $3.33 \mathrm{~m}$ & 76.5 \\
\hline \multirow[t]{2}{*}{6} & & & $3.71 \mathrm{dd}(12.0,5.2)$ & 61.3 & $3.68 \mathrm{dd}(12.0,5.4)$ & 61.2 \\
\hline & & & $3.86 \mathrm{dd}(12.0,2.3)$ & & $3.86 \mathrm{dd}(12.0,2.3)$ & \\
\hline \multicolumn{7}{|l|}{ glc (at C-28) } \\
\hline 1 & $5.37 \mathrm{~d}(8.1)$ & 94.4 & $5.37 \mathrm{~d}(8.2)$ & 94.4 & $5.37 \mathrm{~d}(8.1)$ & 94.3 \\
\hline 2 & $3.34 \mathrm{t}(8.1)$ & 72.5 & $3.35 \mathrm{t}(8.2)$ & 72.4 & $3.36 \mathrm{t}(8.1)$ & 72.5 \\
\hline 3 & $3.42 \mathrm{dd}(9.6,8.1)$ & 76.8 & $3.44 \mathrm{t}(8.2)$ & 76.7 & $3.44 \mathrm{~m}$ & 76.8 \\
\hline 4 & $3.44 \mathrm{t}(9.6)$ & 69.5 & $3.45 \mathrm{t}(8.2)$ & 69.5 & $3.46 \mathrm{t}(9.6)$ & 69.5 \\
\hline 5 & $3.52 \mathrm{~m}$ & 76.4 & $3.52 \mathrm{~m}$ & 76.4 & $3.53 \mathrm{~m}$ & 76.4 \\
\hline \multirow[t]{2}{*}{6} & $3.78 \mathrm{dd}(11.4,4.3)$ & 68.1 & $3.79 \mathrm{dd}(11.4,4.7)$ & 68.1 & $3.79 \mathrm{dd}(11.8,4.1)$ & 68.1 \\
\hline & $4.13 \mathrm{dd}(11.4,1.8)$ & & $4.14 \mathrm{dd}(11.4,1.7)$ & & $4.13 \mathrm{dd}(11.8,2.1)$ & \\
\hline \multicolumn{7}{|l|}{ glc' $^{\prime}$} \\
\hline 1 & $4.36 \mathrm{~d}(7.8)$ & 103.3 & $4.36 \mathrm{~d}(7.8)$ & 103.2 & $4.36 \mathrm{~d}(7.8)$ & 103.1 \\
\hline 2 & $3.22 \mathrm{t}(7.8)$ & 73.6 & $3.22 \mathrm{t}(7.8)$ & 73.7 & $3.23 \mathrm{dd}(8.5,7.8)$ & 73.6 \\
\hline 3 & $3.37 \mathrm{dd}(8.9,7.8)$ & 76.7 & $3.37 \mathrm{dd}(8.3,7.8)$ & 76.8 & $3.37 \mathrm{~m}$ & 76.3 \\
\hline 4 & $3.30 \mathrm{t}(8.9)$ & 70.1 & $3.31 \mathrm{t}(8.3)$ & 70.1 & $3.32 \mathrm{t}(8.5)$ & 70.0 \\
\hline 5 & $3.24 \mathrm{~m}$ & 76.3 & $3.29 \mathrm{~m}$ & 76.6 & $3.27 \mathrm{~m}$ & 76.5 \\
\hline \multirow[t]{2}{*}{6} & $3.69 \mathrm{dd}(11.8,5.4)$ & 61.2 & $3.67 \mathrm{dd}(11.9,5.5)$ & 61.3 & $3.68 \mathrm{dd}(12.0,5.4)$ & 61.2 \\
\hline & $3.86 \mathrm{dd}(11.8,2.5)$ & & $3.86 \mathrm{~m}$ & & $3.86 \mathrm{dd}(12.0,2.3)$ & \\
\hline
\end{tabular}


Table 3. N NMR spectroscopic data for the aglycone moieties for compounds $2,4\left(500 \mathrm{MHz}, \mathrm{CD}_{3} \mathrm{OD}\right)$ and 6 (600 MHz, $\left.\mathrm{CD}_{3} \mathrm{OD}\right)$.

\begin{tabular}{|c|c|c|c|c|c|c|}
\hline Position & 2 & & 4 & & 6 & \\
\hline & $\delta_{\mathrm{H}} \mathrm{m}(J$ in $\mathrm{Hz})$ & $\delta_{\mathrm{C}}$ & $\delta_{\mathrm{H}} \mathrm{m}(J$ in $\mathrm{Hz})$ & $\delta_{\mathrm{C}}$ & $\delta_{\mathrm{H}} \mathrm{m}(J$ in $\mathrm{Hz})$ & $\delta_{\mathrm{C}}$ \\
\hline \multirow[t]{2}{*}{1} & $0.98 \mathrm{~m}$ & 38.7 & $1.00 \mathrm{~m}$ & 38.6 & $0.98 \mathrm{~m}$ & 38.7 \\
\hline & $1.62 \mathrm{~m}$ & & $1.62 \mathrm{~m}$ & & $1.62 \mathrm{~m}$ & \\
\hline \multirow[t]{2}{*}{2} & $1.69 \mathrm{~m}$ & 25.9 & $1.72 \mathrm{~m}$ & 25.8 & $1.69 \mathrm{~m}$ & 25.9 \\
\hline & $1.82 \mathrm{dt}(13.5,3.2)$ & & $1.82 \mathrm{dt}(13.1,3.5)$ & & $1.82 \mathrm{dt}(13.5,3.2)$ & \\
\hline 3 & $3.14 \mathrm{dd}(11.5,4.0)$ & 88.9 & $3.15 \mathrm{dd}(11.8,3.5)$ & 88.8 & $3.14 \mathrm{dd}(11.5,4.0)$ & 88.9 \\
\hline 4 & - & 38.9 & - & 38.8 & - & 38.6 \\
\hline 5 & $0.78 b r d(12.2)$ & 55.9 & $0.80 b r d(12.3)$ & 55.8 & 0.78 brd (12.2) & 55.9 \\
\hline \multirow[t]{2}{*}{6} & $1.42 \operatorname{td}(13.9,3.8)$ & 18.0 & $1.42 \operatorname{td}(13.9,3.8)$ & 17.9 & $1.42 \operatorname{td}(13.9,3.8)$ & 18.0 \\
\hline & $1.56 \mathrm{~m}$ & & $1.55 \mathrm{~m}$ & & $1.56 \mathrm{~m}$ & \\
\hline \multirow[t]{2}{*}{7} & $1.33 \mathrm{~m}$ & 32.5 & $1.34 \mathrm{~m}$ & 31.7 & $1.33 \mathrm{~m}$ & 32.5 \\
\hline & $1.51 \mathrm{~m}$ & & $1.51 \mathrm{~m}$ & & $1.51 \mathrm{~m}$ & \\
\hline 8 & - & 39.3 & - & 39.2 & - & 39.3 \\
\hline 9 & $1.59 \mathrm{~m}$ & 47.9 & $1.59 \mathrm{~m}$ & 47.6 & $1.59 \mathrm{~m}$ & 48.4 \\
\hline 10 & - & 36.5 & - & 36.4 & - & 36.5 \\
\hline 11 & $1.91 \mathrm{~m}$ & 23.2 & $1.91 \mathrm{~m}$ & 23.1 & $1.91 \mathrm{~m}$ & 23.1 \\
\hline 12 & $5.27 \mathrm{t}(3.5)$ & 122.4 & $5.27 \mathrm{t}(3.8)$ & 122.3 & $5.27 \mathrm{t}(3.5)$ & 121.8 \\
\hline 13 & - & 143.5 & - & 143.4 & - & 143.5 \\
\hline 14 & - & 41.4 & - & 41.4 & - & 41.6 \\
\hline \multirow[t]{2}{*}{15} & $1.10 \mathrm{~m}$ & 27.5 & $1.10 \mathrm{dt}(13.1,3.5)$ & 27.4 & $1.06 \mathrm{~m}$ & 27.6 \\
\hline & $1.80 \mathrm{~m}$ & & $1.81 \mathrm{td}(13.1,3.5)$ & & $1.82 \mathrm{~m}$ & \\
\hline \multirow[t]{2}{*}{16} & $1.73 \mathrm{~m}$ & 22.6 & $1.73 \mathrm{~m}$ & 22.6 & $1.62 \mathrm{~m}$ & 22.8 \\
\hline & $2.07 \operatorname{td}(13.7,3.0)$ & & $2.07 \operatorname{td}(13.8,3.7)$ & & $1.98 \operatorname{td}(13.7,3.0)$ & \\
\hline 17 & - & 46.7 & - & 46.6 & - & 46.7 \\
\hline 18 & $2.88 \mathrm{dd}(13.8,3.9)$ & 41.2 & $2.88 \mathrm{dd}(13.7,4.9)$ & 41.1 & $2.88 \mathrm{dd}(13.8,3.9)$ & 41.6 \\
\hline \multirow{2}{*}{19} & $1.17 \mathrm{~m}$ & 45.9 & $1.17 \mathrm{~m}$ & 45.8 & $1.13 \mathrm{~m}$ & 45.9 \\
\hline & $1.72 \mathrm{~m}$ & & $1.74 \mathrm{~m}$ & & $1.70 \mathrm{~m}$ & \\
\hline 20 & - & 30.1 & - & 30.1 & - & 30.1 \\
\hline \multirow[t]{2}{*}{21} & $1.23 \mathrm{~m}$ & 33.5 & $1.24 \mathrm{~m}$ & 33.4 & $1.20 \mathrm{~m}$ & 33.7 \\
\hline & $1.40 \mathrm{~m}$ & & $1.41 \mathrm{~m}$ & & $1.40 \mathrm{~m}$ & \\
\hline \multirow[t]{2}{*}{22} & $1.61 \mathrm{~m}$ & 31.8 & $1.61 \mathrm{~m}$ & 32.5 & $1.56 \mathrm{~m}$ & 31.8 \\
\hline & $1.73 \mathrm{~m}$ & & $1.73 \operatorname{td}(12.5,3.5)$ & & $1.76 \mathrm{~m}$ & \\
\hline 23 & $1.07 \mathrm{~s}$ & 27.5 & $1.07 \mathrm{~s}$ & 27.0 & $1.07 \mathrm{~s}$ & 27.5 \\
\hline 24 & $0.88 \mathrm{~s}$ & 15.8 & $0.88 \mathrm{~s}$ & 15.8 & $0.88 \mathrm{~s}$ & 15.8 \\
\hline 25 & $0.98 \mathrm{~s}$ & 14.8 & $0.98 \mathrm{~s}$ & 14.7 & $0.98 \mathrm{~s}$ & 14.6 \\
\hline 26 & $0.82 \mathrm{~s}$ & 16.4 & $0.82 \mathrm{~s}$ & 16.6 & $0.86 \mathrm{~s}$ & 16.5 \\
\hline 27 & $1.18 \mathrm{~s}$ & 24.9 & $1.18 \mathrm{~s}$ & 24.8 & $1.18 \mathrm{~s}$ & 24.9 \\
\hline 28 & - & 176.7 & - & 176.6 & - & 179.8 \\
\hline 29 & $0.93 \mathrm{~s}$ & 32.1 & $0.93 \mathrm{~s}$ & 32.0 & $0.93 \mathrm{~s}$ & 32.3 \\
\hline 30 & $0.96 \mathrm{~s}$ & 22.6 & $0.96 \mathrm{~s}$ & 22.6 & $0.96 \mathrm{~s}$ & 22.7 \\
\hline
\end{tabular}


Table 4. NMR spectroscopic data of the sugar moieties for compounds $2,4\left(500 \mathrm{MHz}, \mathrm{CD}_{3} \mathrm{OD}\right)$ and 6 (600 $\mathrm{MHz}, \mathrm{CD}_{3} \mathrm{OD}$ ).

\begin{tabular}{|c|c|c|c|c|c|c|}
\hline \multirow[b]{3}{*}{ xyl at C-3 } & \multicolumn{2}{|l|}{2} & \multicolumn{2}{|l|}{4} & \multicolumn{2}{|l|}{6} \\
\hline & $\delta_{\mathrm{H}} \mathrm{m}(J$ in $\mathrm{Hz})$ & $\delta_{\mathrm{C}}$ & $\delta_{\mathrm{H}} \mathrm{m}(J$ in $\mathrm{Hz})$ & & $\delta_{\mathrm{H}} \mathrm{m}(J$ in $\mathrm{Hz})$ & $\delta_{\mathrm{C}}$ \\
\hline & & & & & & \\
\hline 1 & $4.39 \mathrm{~d}(7.1)$ & 105.0 & $4.39 \mathrm{~d}(7.1)$ & 104.9 & $4.40 \mathrm{~d}(7.2)$ & 105.0 \\
\hline 2 & $3.40 \mathrm{~m}$ & 76.8 & $3.34 \mathrm{dd}(8.1,7.0)$ & 76.7 & $3.40 \mathrm{dd}(8.2,7.2)$ & 76.8 \\
\hline 3 & $3.44 \mathrm{t}(8.2)$ & 77.4 & $3.45 \mathrm{t}(8.0)$ & 77.4 & $3.45 \mathrm{t}(8.2)$ & 77.4 \\
\hline 4 & 3.47 brt (8.2) & 70.2 & $3.47 \mathrm{~m}$ & 70.2 & $3.48 \mathrm{~m}$ & 70.2 \\
\hline \multirow[t]{2}{*}{5} & $3.19 \mathrm{dd}(11.4,9.0)$ & 65.2 & $3.21 \mathrm{dd}(10.5,9.1)$ & 65.1 & $3.19 \mathrm{dd}(10.5,9.1)$ & 65.1 \\
\hline & $3.86 \mathrm{dd}(11.4,5.1)$ & & $3.85 \mathrm{dd}(10.5,5.2)$ & & $3.86 \mathrm{dd}(10.5,5.2)$ & \\
\hline \multicolumn{7}{|c|}{ 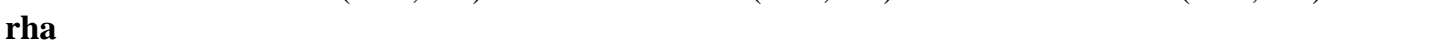 } \\
\hline 1 & $5.39 \mathrm{~d}(1.7)$ & 99.9 & $5.38 \mathrm{~d}(1.7)$ & 99.9 & $5.38 \mathrm{~d}(1.7)$ & 99.9 \\
\hline 2 & $4.13 \mathrm{dd}(2.9,1.7)$ & 70.2 & $4.13 \mathrm{dd}(3.1,1.7)$ & 70.1 & $4.13 \mathrm{dd}(3.0,1.7)$ & 70.1 \\
\hline 3 & $3.90 \mathrm{dd}(9.5,2.9)$ & 80.8 & $3.90 \mathrm{dd}(9.5,3.1)$ & 80.7 & $3.90 \mathrm{dd}(9.5,3.0)$ & 80.7 \\
\hline 4 & $3.58 \mathrm{t}(9.5)$ & 71.4 & $3.58 \mathrm{t}(9.5)$ & 71.3 & $3.53 \mathrm{t}(9.5)$ & 71.4 \\
\hline 5 & $4.00 \mathrm{dq}(8.4,6.9)$ & 68.4 & $4.01 \mathrm{~m}$ & 68.5 & $3.99 \mathrm{~m}$ & 68.5 \\
\hline 6 & $1.25 \mathrm{~d}(6.9)$ & 16.6 & $1.25 \mathrm{~d}(6.2)$ & 16.6 & $1.25 \mathrm{~d}(6.2)$ & 16.6 \\
\hline \multicolumn{7}{|l|}{$\mathbf{x y l}^{\prime}$} \\
\hline 1 & $4.48 \mathrm{~d}(7.7)$ & 105.1 & $4.47 \mathrm{~d}(7.7)$ & 105.0 & $4.47 \mathrm{~d}(7.7)$ & 105.0 \\
\hline 2 & $3.40 \mathrm{dd}(8.9,7.7)$ & 74.4 & $3.40 \mathrm{dd}(8.8,7.7)$ & 74.4 & $3.40 \mathrm{dd}(8.8,7.7)$ & 74.5 \\
\hline 3 & $3.48 \mathrm{t}(8.9)$ & 82.1 & $3.49 \mathrm{t}(8.8)$ & 81.6 & $3.49 \mathrm{t}(8.8)$ & 81.7 \\
\hline 4 & 3.54 brt (8.9) & 68.6 & $3.53 \mathrm{~m}$ & 68.3 & $3.53 \mathrm{~m}$ & 68.3 \\
\hline \multirow[t]{2}{*}{5} & $3.22 \mathrm{dd}(10.9,8.0)$ & 65.7 & $3.24 \mathrm{dd}(11.4,10.1)$ & 65.6 & $3.24 \mathrm{dd}(11.3,10.0)$ & 65.7 \\
\hline & $3.90 \mathrm{~m}$ & & $3.88 \mathrm{dd}(11.4,2.3)$ & & $3.88 \mathrm{dd}(11.3,2.3)$ & \\
\hline \multicolumn{7}{|l|}{ rha' } \\
\hline 1 & $5.20 \mathrm{~d}(1.7)$ & 101.1 & $5.21 \mathrm{~d}(1.6)$ & 100.7 & $5.21 \mathrm{brs}$ & 100.7 \\
\hline 2 & $3.96 \mathrm{dd}(3.3,1.7)$ & 70.9 & $3.97 \mathrm{dd}(3.3,1.6)$ & 70.8 & $3.98 \mathrm{dd}(3.3,1.2)$ & 70.8 \\
\hline 3 & 3.72 dd $(9.5,3.3)$ & 70.8 & 3.96 dd $(9.2,3.3)$ & 70.7 & 3.97 dd $(9.2,3.3)$ & 70.9 \\
\hline 4 & $3.41 \mathrm{t}(9.5)$ & 72.6 & $3.64 \mathrm{t}(9.2)$ & 82.2 & $3.63 \mathrm{t}(9.2)$ & 82.6 \\
\hline 5 & $4.03 \mathrm{dq}(9.5,6.5)$ & 68.4 & $4.12 \mathrm{~m}$ & 67.1 & $4.13 \mathrm{~m}$ & 67.1 \\
\hline 6 & $1.28 \mathrm{~d}(6.5)$ & 16.5 & $1.34 \mathrm{~d}(6.2)$ & 16.3 & $1.34 \mathrm{~d}(6.2)$ & 16.6 \\
\hline \multicolumn{3}{|l|}{ glc" } & & & glc" at rha'-C-4 & \\
\hline 1 & & & $4.61 \mathrm{~d}(7.9)$ & 104.6 & $4.64 \mathrm{~d}(7.9)$ & 104.2 \\
\hline 2 & & & $3.22 \mathrm{t}(8.4)$ & 74.6 & $3.29 \mathrm{t}(8.5)$ & 74.4 \\
\hline 3 & & & $3.39 \mathrm{t}(8.4)$ & 76.6 & $3.55 \mathrm{t}(8.4)$ & 75.2 \\
\hline 4 & & & $3.33 \mathrm{~m}$ & 71.3 & $3.61 \mathrm{t}(8.4)$ & 79.1 \\
\hline 5 & & & $3.30 \mathrm{~m}$ & 76.5 & $3.42 \mathrm{~m}$ & 75.2 \\
\hline \multirow[t]{2}{*}{6} & & & $3.68 \mathrm{dd}(11.9,5.5)$ & 61.2 & $3.90 \mathrm{~m}$ & 60.4 \\
\hline & & & $3.86 \mathrm{dd}(11.9,2.2)$ & & $3.90 \mathrm{~m}$ & \\
\hline glc (at C-28) & glc at C-28 & & glc at C-28 & & glc at glc ${ }^{\prime \prime}-\mathrm{C}-4$ & \\
\hline 1 & $5.37 \mathrm{~d}(8.0)$ & 94.4 & $5.37 \mathrm{~d}(8.1)$ & 94.3 & $4.48 \mathrm{~d}(8.0)$ & 103.0 \\
\hline 2 & $3.34 \mathrm{~m}$ & 72.5 & $3.35 \mathrm{~m}$ & 72.4 & $3.31 \mathrm{dd}(8.5,8.0)$ & 73.3 \\
\hline 3 & $3.43 \mathrm{t}(8.5)$ & 76.8 & $3.44 \mathrm{t}(8.8)$ & 76.6 & $3.55 \mathrm{t}(8.5)$ & 74.8 \\
\hline 4 & $3.44 \mathrm{t}(8.5)$ & 69.5 & $3.42 \mathrm{t}(8.8)$ & 69.4 & $3.61 \mathrm{t}(8.5)$ & 78.8 \\
\hline 5 & $3.52 \mathrm{~m}$ & 76.4 & $3.51 \mathrm{~m}$ & 76.3 & $3.49 \mathrm{~m}$ & 75.2 \\
\hline \multirow[t]{2}{*}{6} & $3.78 \mathrm{dd}(11.7,5.0)$ & 68.1 & $3.79 \mathrm{dd}(11.7,5.0)$ & 68.0 & $3.83 \mathrm{~m}$ & 60.1 \\
\hline & $4.14 \mathrm{dd}(11.7,2.0)$ & & $4.14 \mathrm{dd}(11.7,1.6)$ & & $3.93 \mathrm{~m}$ & \\
\hline glc $^{\prime}$ & glc $^{\prime} \rightarrow$ glc-C-6 & & glc $^{\prime} \rightarrow$ glc-C-6 & & glc'at glc-C-4 & \\
\hline 1 & $4.36 \mathrm{~d}(7.8)$ & 103.2 & $4.36 \mathrm{~d}(7.8)$ & 103.2 & $4.42 \mathrm{~d}(7.9)$ & 103.2 \\
\hline 2 & $3.21 \mathrm{dd}(8.6,7.8)$ & 73.7 & $3.22 \mathrm{dd}(8.4,7.8)$ & 73.6 & $3.24 \mathrm{dd}(8.6,7.9)$ & 73.5 \\
\hline 3 & 3.37 t (8.6) & 76.6 & $3.38 \mathrm{t}(8.4)$ & 76.8 & $3.38 \mathrm{t}(8.6)$ & 76.4 \\
\hline 4 & $3.31 \mathrm{t}(8.6)$ & 70.2 & $3.31 \mathrm{t}(8.5)$ & 70.1 & $3.33 \mathrm{~m}$ & 69.9 \\
\hline 5 & $3.27 \mathrm{~m}$ & 76.6 & $3.27 \mathrm{~m}$ & 76.5 & $3.36 \mathrm{~m}$ & 76.6 \\
\hline \multirow[t]{2}{*}{6} & $3.68 \mathrm{dd}(12.0,5.5)$ & 61.3 & $3.68 \mathrm{dd}(11.9,5.5)$ & 61.2 & $3.68 \mathrm{dd}(11.8,5.5)$ & 61.0 \\
\hline & $3.86 \mathrm{dd}(12.0,2.0)$ & & $3.86 \mathrm{dd}(11.9,2.2)$ & & $3.90 \mathrm{dd}(11.8,2.2)$ & \\
\hline
\end{tabular}


Table 5. NMR spectroscopic data of the aglycone moieties for compounds 7 and $\mathbf{8}\left(500 \mathrm{MHz}, \mathrm{CD}_{3} \mathrm{OD}\right)$.

\begin{tabular}{|c|c|c|c|c|}
\hline position & 7 & & 8 & \\
\hline \multirow{3}{*}{1} & $\delta_{\mathrm{H}} \mathrm{m}(J$ in $\mathrm{Hz})$ & $\delta_{\mathrm{C}}$ & $\delta_{\mathrm{H}} \mathrm{m}(J$ in $\mathrm{Hz})$ & $\delta_{\mathrm{C}}$ \\
\hline & $0.98 \mathrm{~m}$ & 38.3 & $0.92 \mathrm{~m}$ & 46.8 \\
\hline & $1.62 \mathrm{~m}$ & & $2.05 \mathrm{dd}(11.1,4.2)$ & \\
\hline \multirow[t]{2}{*}{2} & $1.78 \mathrm{~m}$ & 25.1 & $3.82 \mathrm{~m}$ & 66.4 \\
\hline & $1.97 \mathrm{~m}$ & & & \\
\hline 3 & $3.66 \mathrm{dd}(11.5,3.7)$ & 82.3 & $3.54 \mathrm{~d}(9.5)$ & 86.1 \\
\hline 4 & - & 42.7 & - & 44.1 \\
\hline 5 & $1.25 \mathrm{~m}$ & 46.9 & $1.35 \mathrm{~m}$ & 46.3 \\
\hline \multirow[t]{2}{*}{6} & $1.39 \mathrm{~m}$ & 17.5 & $1.36 \mathrm{~m}$ & 17.4 \\
\hline & $1.49 \mathrm{~m}$ & & $1.49 \mathrm{~m}$ & \\
\hline \multirow[t]{2}{*}{7} & $1.29 \mathrm{~m}$ & 32.0 & $1.31 \mathrm{~m}$ & 32.2 \\
\hline & $1.60 \mathrm{~m}$ & & $1.70 \operatorname{td}(13.5,3.5)$ & \\
\hline 8 & - & 39.3 & - & 39.4 \\
\hline 9 & $1.64 \mathrm{~m}$ & 47.9 & $1.63 \mathrm{~m}$ & 47.9 \\
\hline 10 & - & 36.2 & - & 37.2 \\
\hline 11 & $1.92 \mathrm{~m}$ & 23.2 & $1.99 \mathrm{~m}$ & 23.1 \\
\hline 12 & $5.27 \mathrm{t}(3.4)$ & 122.4 & $5.27 \mathrm{t}(3.4)$ & 125.7 \\
\hline 13 & - & 143.5 & - & 137.1 \\
\hline 14 & - & 41.6 & - & 42.1 \\
\hline \multirow[t]{2}{*}{15} & $1.11 \mathrm{~m}$ & 27.5 & $1.11 \mathrm{~m}$ & 27.8 \\
\hline & $1.80 \mathrm{~m}$ & & $1.98 \operatorname{td}(13.3,4.2)$ & \\
\hline \multirow[t]{2}{*}{16} & $1.73 \mathrm{~m}$ & 22.6 & $1.78 \mathrm{dt}(13.0,4.2)$ & 23.8 \\
\hline & $2.07 \mathrm{~m}$ & & $2.10 \operatorname{td}(13.0,4.2)$ & \\
\hline 17 & - & 46.7 & - & 47.5 \\
\hline 18 & $2.87 \mathrm{dd}(14.1,4.3)$ & 41.2 & $2.26 \mathrm{~d}(11.4)$ & 52.8 \\
\hline \multirow[t]{2}{*}{19} & $1.28 \mathrm{~m}$ & 45.8 & $1.41 \mathrm{~m}$ & 39.0 \\
\hline & $1.73 \mathrm{~m}$ & & & \\
\hline 20 & & 30.1 & $0.98 \mathrm{~m}$ & 39.038 .9 \\
\hline \multirow[t]{2}{*}{21} & $1.23 \mathrm{~m}$ & 33.5 & $1.37 \mathrm{~m}$ & 30.3 \\
\hline & $1.40 \mathrm{~m}$ & & $1.52 \operatorname{td}(13.1,4.1)$ & \\
\hline \multirow[t]{2}{*}{22} & $1.62 \mathrm{~m}$ & 31.8 & $1.66 \mathrm{~m}$ & 36.1 \\
\hline & $1.73 \mathrm{~m}$ & & $1.78 \mathrm{dt}(13.0,4.2)$ & \\
\hline \multirow[t]{2}{*}{23} & $3.27 \mathrm{~d}(11.2)$ & 63.4 & $3.30 \mathrm{~d}(11.8)$ & 62.7 \\
\hline & $3.75 \mathrm{~d}(11.2)$ & & $3.70 \mathrm{~d}(11.8)$ & \\
\hline 24 & $0.72 \mathrm{~s}$ & 12.0 & $0.78 \mathrm{~s}$ & 13.6 \\
\hline 25 & $1.00 \mathrm{~s}$ & 15.2 & $1.07 \mathrm{~s}$ & 16.5 \\
\hline 26 & $0.82 \mathrm{~s}$ & 16.5 & $0.87 \mathrm{~s}$ & 16.4 \\
\hline 27 & $1.19 \mathrm{~s}$ & 25.0 & $1.15 \mathrm{~s}$ & 22.6 \\
\hline 28 & - & 175.7 & - & 176.7 \\
\hline 29 & $0.92 \mathrm{~s}$ & 32.1 & $0.92 \mathrm{~d}(6.3)$ & 16.2 \\
\hline 30 & $0.95 \mathrm{~s}$ & 22.6 & $0.99 \mathrm{~d}(6.3)$ & 20.1 \\
\hline
\end{tabular}


Table 6. NMR spectroscopic data of the sugar moieties for compounds $\mathbf{7}$ and $\mathbf{8}\left(500 \mathrm{MHz}, \mathrm{CD}_{3} \mathrm{OD}\right)$.

\begin{tabular}{|c|c|c|c|c|}
\hline position & 7 & & 8 & \\
\hline & $\delta_{\mathrm{H}} \mathrm{m}(J$ in $\mathrm{Hz})$ & $\delta_{\mathrm{C}}$ & $\delta_{\mathrm{H}} \mathrm{m}(J$ in $\mathrm{Hz})$ & $\delta_{\mathrm{C}}$ \\
\hline \multicolumn{5}{|c|}{ glcA at C-3 } \\
\hline 1 & $4.56 \mathrm{~d}(7.5)$ & 102.8 & $4.55 \mathrm{~d}(7.5)$ & 102.4 \\
\hline 2 & $3.57 \mathrm{dd}(9.0,7.5)$ & 80.2 & $3.49 \mathrm{dd}(9.4,7.5)$ & 78.0 \\
\hline 3 & $3.63 \mathrm{t}(9.0)$ & 76.9 & $3.56 \mathrm{t}(9.4)$ & 77.4 \\
\hline 4 & $3.47 \mathrm{t}(9.0)$ & 72.1 & $3.47 \mathrm{t}(9.4)$ & 72.6 \\
\hline 5 & $3.58 \mathrm{~d}(9.0)$ & 74.9 & $3.64 \mathrm{~d}(9.4)$ & 75.0 \\
\hline 6 & & 176.2 & & 176.5 \\
\hline glc/rha & glc at glcA-C-2 & & rha at glcA-C-2 & \\
\hline 1 & $4.71 \mathrm{~d}(7.7)$ & 103.2 & $5.34 \mathrm{~d}(1.6)$ & 101.0 \\
\hline 2 & $3.24 \mathrm{t}(8.3)$ & 74.8 & $4.06 \mathrm{dd}(3.1,1.6)$ & 70.3 \\
\hline 3 & $3.36 \mathrm{~m}$ & 76.4 & $3.81 \mathrm{dd}(9.2,3.1)$ & 70.6 \\
\hline 4 & $3.26 \mathrm{t}(8.5)$ & 70.3 & $3.40 \mathrm{t}(9.2)$ & 72.5 \\
\hline 5 & $3.25 \mathrm{~m}$ & 76.9 & $3.91 \mathrm{dq}(9.5,6.3)$ & 69.0 \\
\hline \multirow[t]{2}{*}{6} & $3.65 \mathrm{~m}$ & 61.5 & $1.25 \mathrm{~d}(6.3)$ & 16.7 \\
\hline & $3.82 \mathrm{dd}(12.0,2.1)$ & & & \\
\hline \multicolumn{5}{|c|}{ glc at C-28 } \\
\hline 1 & $5.37 \mathrm{~d}(8.1)$ & 94.4 & $5.37 \mathrm{~d}(8.1)$ & 94.3 \\
\hline 2 & $3.34 \mathrm{~m}$ & 72.5 & $3.34 \mathrm{~m}$ & 72.5 \\
\hline 3 & $3.42 \mathrm{t}(8.4)$ & 76.4 & $3.42 \mathrm{t}(8.7)$ & 76.9 \\
\hline 4 & $3.44 \mathrm{t}(8.4)$ & 69.5 & $3.38 \mathrm{t}(8.7)$ & 69.8 \\
\hline 5 & $3.52 \mathrm{~m}$ & 76.9 & $3.34 \mathrm{~m}$ & 77.2 \\
\hline \multirow[t]{2}{*}{6} & $3.77 \mathrm{~m}$ & 68.1 & $3.71 \mathrm{dd}(12.0,1.2)$ & 61.1 \\
\hline & $4.14 \mathrm{dd}(12.2,1.6)$ & & $3.82 \mathrm{dd}(12.0,3.8)$ & \\
\hline \multicolumn{5}{|c|}{ glc' at glc-C-6 } \\
\hline 1 & $4.36 \mathrm{~d}(7.8)$ & 103.2 & & \\
\hline 2 & $3.23 \mathrm{t}(7.8)$ & 72.5 & & \\
\hline 3 & $3.37 \mathrm{~m}$ & 76.4 & & \\
\hline 4 & $3.31 \mathrm{t}(8.6)$ & 70.3 & & \\
\hline 5 & $3.32 \mathrm{~m}$ & 76.9 & & \\
\hline \multirow[t]{2}{*}{6} & $3.69 \mathrm{~m}$ & 61.3 & & \\
\hline & $3.86 \mathrm{dd}(12.2,1.2)$ & & & \\
\hline
\end{tabular}




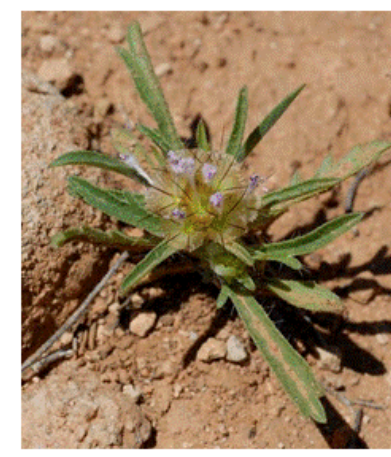

Scabiosa stellata Cav. (Caprifoliaceae)

- 8 previously undescribed saponins - 3 known compounds

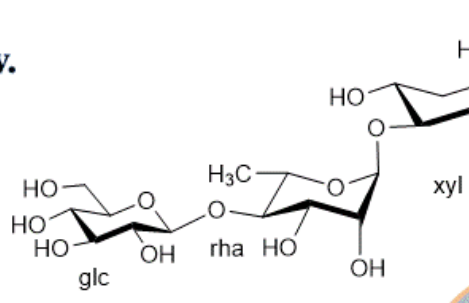

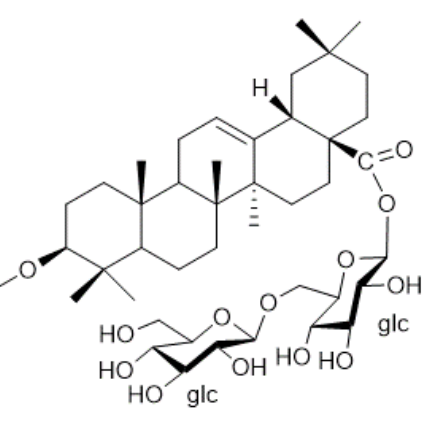

Compound 4

Cytotoxic activity against fibrosarcoma cell line (HT1080)

Good cytotoxic activity $\left(\mathrm{IC}_{50} 12.0 \pm 0.2 \mu \mathrm{M}\right)$ 